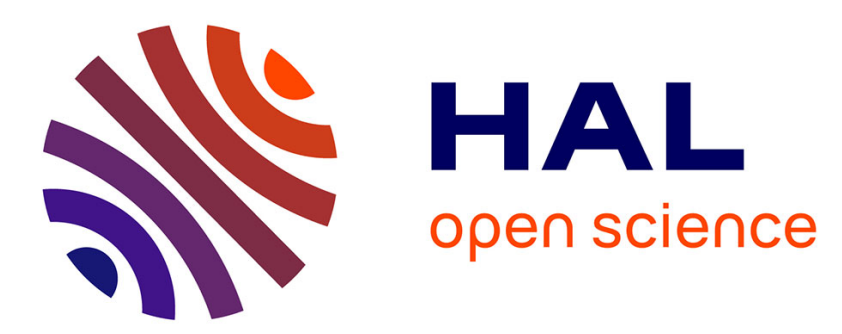

\title{
Friends or foes? Mobile money interaction with formal and informal finance
}

Serge Ky, Clovis Rugemintwari, Alain Sauviat

\section{To cite this version:}

Serge Ky, Clovis Rugemintwari, Alain Sauviat. Friends or foes? Mobile money interaction with formal and informal finance. 2019. hal-02000982

\section{HAL Id: hal-02000982 \\ https://hal-unilim.archives-ouvertes.fr/hal-02000982}

Preprint submitted on 6 Feb 2019

HAL is a multi-disciplinary open access archive for the deposit and dissemination of scientific research documents, whether they are published or not. The documents may come from teaching and research institutions in France or abroad, or from public or private research centers.
L'archive ouverte pluridisciplinaire HAL, est destinée au dépôt et à la diffusion de documents scientifiques de niveau recherche, publiés ou non, émanant des établissements d'enseignement et de recherche français ou étrangers, des laboratoires publics ou privés. 


\title{
Friends or foes? Mobile money interaction with formal and informal finance
}

\author{
Serge Ky ${ }^{\text {a, }}{ }^{\dagger}$, Clovis Rugemintwari ${ }^{b}$, and Alain Sauviat ${ }^{b}$ \\ ${ }^{a}$ Université de Ouahigouya, Laboratoire d'Analyse et de Politique Économiques, Burkina Faso \\ ${ }^{b}$ Université de Limoges, Laboratoire d'Analyse et de Prospective Économiques, France
}

\section{This version: November 4, 2018}

\begin{abstract}
Access to and usage of formal financial services are important determinants of financial inclusion and yet, informal mechanisms still dominate the financial system in developing countries. In this context, the purpose of our paper is to investigate how the growing effort to harness mobile money may play a role to overcome barriers that prevent people to access formal financial services. Using a unique dataset obtained from an individual-level survey conducted in Burkina Faso, we explore the interplay between mobile money innovation as a deposit instrument and pre-existing formal and informal financial instruments. Our main findings show that, overall, the use of mobile money is not associated with deposits using formal and/or informal financial instruments. However, a closer investigation reveals suggestive evidence that it increases the probability of participants in informal mechanisms to make deposits in a bank account. Moreover, considering disadvantaged groups, we find for women, irregular income and less educated individuals that mobile money may increase their probability to make deposits in a bank and/or credit union accounts. Given the low access to formal financial services in developing countries, our findings taken together indicate how the increasing adoption of mobile money may act as a stepping-stone towards financial inclusion. (JEL Classification C83, D14, G21, G23, O12)
\end{abstract}

Keywords: mobile money, formal finance, informal finance, deposit behavior, financial inclusion, developing countries

\footnotetext{
${ }^{\dagger}$ Corresponding Author. Tel: + 335551492 51. E-mail address: serge.ky@unilim.fr
} 


\section{Introduction}

The financial services needs of low-income people in developing countries, which have long been excluded from the formal financial system, are receiving an increasing attention from researchers, governments, international organizations and even bank institutions. Access to formal financial services enables households to anticipate, adapt to and/or recover from the effects of shocks in a manner that protects their livelihoods, reduces chronic vulnerability and facilitates growth (Gash and Gray, 2015). Despite its importance, access to formal financial institutions remains very low in developing countries as it stands at around two out of five people (Demirguckunt and Klapper, 2012). One major issue associated with this lack of access to formal financial services is individuals' difficulty to make deposits that they can subsequently allocate to savings, investments, coping with emergencies or smoothing consumption. Consequently, informal financial mechanisms, although risky, remain the main channel through which individuals manage their finances. However, while these informal instruments are useful, they are not regulated (Christensen, 1993; De Koker and Jentzsch, 2013) and the predominance of informal financial sector in collecting deposits is usually an indicator of the inefficiency of formal financial institutions to satisfy the financial needs of the population. In these circumstances, individuals' decision to make deposits entails ingenious, often costly, mechanisms and comes with different motivations such as transfers, payments, insurance against emergencies, and savings (Ambrosius and Cuecuecha, 2015).

In the last decade, there has been a massive effort to harness technology in order to overcome barriers that prevent poor people from accessing banking services. In this way emerged the financial innovation of mobile money. Mobile money innovation refers to the use of a mobile phone to perform financial transactions such as remittances, payment of bills, purchase of goods and services, and savings through cash in and cash out functions. The cell phone acts as an electronic wallet based on the technology of short messaging services that do not require access to internet to transfer money, make payment, and to store cash value. The distinguishing feature at the core of this paper is that mobile money account can be accessed without having an account at a financial institution but mobile money users who already possess a bank account have the possibility to connect both accounts (Lepoutre and Oguntoye, 2018). Therefore, the conditions of formal financial access, the nature of informal financial mechanisms and the increased access to 
mobile phone may increase the demand for mobile money services (Beise, 2004; Van Der Boor et al., 2014; Maurer, 2012; Murendo et al., 2017; Della Peruta, 2018). In many developing countries, mobile money has revolutionized money transfer systems by reducing the exorbitant monetary and security costs of money transfers with traditional tools (Aron, 2017; Jack and Suri, 2014; Mas, 2012a; Mbiti and David Weil, 2016; Morawczynski and Pickens, 2009). Mobile money not only reduces transaction costs but also increases individuals' convenience in making safe deposits (Ky et al., 2018), and minimizes the need of costly physical infrastructure as well as branch networks (Economides and Jeziorski, 2016; Kendall, et al., 2013). This financial innovation relies on retail networks or mobile money agents that interact with mobile money providers and also guarantee the conversion of cash into electronic money and vice versa for customers. Thus, the availability of mobile money agents who, by the way, must hold sufficient liquidity or e-money to ensure the efficiency of the conversion between e-money and cash, is hence essential for mobile money users to have convenient access to cash in/out options.

Despite growing rapidly, there is a limited body of empirical research on mobile money innovation, in general, and, to the best of our knowledge, little has investigated to date its role in the choices of either formal or informal deposit vehicles. Precisely, evidence on the substitutability and/or complementarity effects of mobile money on the use of formal and/or informal financial instruments is still lacking. The bulk of existing literature is descriptive in nature mainly due to the shortage of individual-level data. Our paper aims at filling this gap by empirically examining how mobile money interacts with formal and informal financial services. Dermish et al. (2012) argue that branchless banking takes the advantage of growing mobile networks to bring banking services into every day retail stores, thereby alleviating the lack of banking infrastructure in the area where poor people live and work. Mas (2012) documents that mobile money has the potential to enhance the relationship between banks and their clients as customers can guide banks to what their needs are. This may in return allow banks to provide them the right formal financial products (Oliveira and Von Hippel, 2011). Furthermore, Morawczynski and Pickens (2009), and Van Der Boor et al. (2014) argue analytically that individuals use M-PESA as a substitute for informal methods of savings, especially keeping money under mattresses at home. By contrast, De Koker and Jentzsch (2013) who use household surveys conducted in eight African countries find that holding a bank account is not negatively associated with the probability of using informal finance. More specifically, they show that an increase in the access to formal financial services including usage 
of mobile banking for receipt of salary or income payments does not reduce the usage of informal financial services such as membership of savings club. More related to our study, Mbiti and Weil (2016) who use two waves of individual-level data in Kenya find that the use of M-Pesa lowers the propensity of people to use informal savings mechanisms, but raises their probability of being banked. However, their results are limited to a shift of savings from informal to M-Pesa since they do not study changes in the use of formal savings methods. In this paper, we empirically investigate how mobile money innovation influences individuals' deposits, particularly the channel by which they are made - through formal or informal means. Our paper contributes to the existent literature in two main ways. First, we investigate whether mobile money improves access to formal financial deposit instruments for individuals participating in informal mechanisms. Second, we test the effect of the use of mobile money on the likelihood of disadvantaged individuals (those with low and irregular incomes, living in rural areas, women and less educated) to make deposits in formal financial instruments; namely bank and credit union accounts. To our knowledge, our paper is the first to tackle such issues.

To perform our empirical analysis, we use data from a survey that we conducted between May and June 2014 in Burkina Faso ${ }^{1}$ a Sub-Saharan African country where mobile money has been recently (2012) introduced with the support of government and private sector. Our findings show that, overall, mobile money has no effect on the propensity to deposit money using either formal or informal instruments. However, a focus on participants in informal mechanisms reveals that mobile money is positively associated with making deposits using bank accounts. Mobile money has the capacity to improve access to formal finance services for these individuals even if they might as well continue to use informal instruments. We find similar results when we consider disadvantaged people. For women and individuals with irregular income mobile money is positively associated with deposits in a bank account while for less educated people, this relationship is found for both bank and credit union accounts.

The remainder of the paper is organized as follows. In section 2, we present the interaction between mobile money innovation and the usage of pre-existing deposit services and derive our testable hypotheses. Section 3 provides the background on mobile money adoption and financial access in Burkina Faso, and also describes our data collection and summary statistics. Section 4 
lays out our methodology and discusses the endogeneity issue. Section 5 presents the results while the last section concludes the paper.

\section{Interaction between mobile money innovation and pre-existing deposit instruments}

The aforementioned literature highlights that the main reason why people in developing countries participate into informal financial mechanisms is due to the lack of access to formal financial services (Chowa et al., 2012; Demirguc-Kunt et al., 2015; Munyegera and Matsumoto, 2016). Introducing the technology of mobile money that straddles formal and informal financial mechanisms may be a catalyst of changes in the choices of deposit instruments. In fact, the literature distinguishes two ways through which mobile financial technology affects the usage of existent financial services: transformative and additive models. The first model entails access of excluded to formal financial products, including transfers and payment through mobile money whereas the second model indicates the usage of mobile phone as another channel to access an existing formal financial account (Mas and Porteous, 2015; Porteous, 2006). We go beyond this mutually exclusive vision of both models and assess the potential effects of mobile money on individuals' deposit behavior in a country where formal and informal finances co-exist.

Mobile money may foster financial inclusion by improving access to formal deposit services. The changes may not only stem from the way individuals conduct their financial transactions such as remittances but also in their choices of methods for deposit holdings. Nevertheless, these effects may also depend on individuals' demographic and socioeconomic characteristics (level and type of income, location, gender, and education level) as we detail below.

\subsection{Mobile money and usage of formal deposit instruments}

A well-developed formal financial system is critical in providing individuals with deposit instruments that allow them to smooth income and consumption over time and make efficient investments in health, education and business. The institutions involved in formal financial services mainly consist of banks, postal banks, credit unions, and insurance companies and are subject to laws, regulations and prudential supervision (Demirgüç-kunt and Levine, 2008; De Koker and Jentzsch, 2013; Pande et al., 2012). The agreement between formal financial institutions and their 
customers is typically governed by formal written contracts, often in the form of standard agreements which are, at least theoretically, enforceable in court.

Despite their advantages, access and usage of formal financial services remain limited in developing countries. For instance, less than a quarter of adults in Sub-Saharan Africa have access to formal financial services (IFC, 2013). Frequent reasons cited for this include the lack of enough money, the fixed fees and high costs of opening and maintaining accounts, distance and insufficient documentation (Thorsten Beck et al., 2008; Demirgüç-Kunt and Klapper, 2012; Honohan and Beck, 2007; Kendall, 2010; Mas, 2010). Weak financial institutions and the cost of maintaining branches in remote areas where unbanked people are mainly located also explain the low level of access and usage of formal financial services. Thus, mobile money appears to have the potential to overcome these barriers by facilitating individuals' access to financial services through their mobile phones. In this situation, mobile money may act as a substitute to formal financial services especially for poor people or for those living in unbanked locations.

In developing countries, individuals often spend time and money to travel long distance to reach branches to make deposits or withdrawals (Beck et al., 2008; Christen and Mas, 2009). This situation may induce account owners to decrease the usage of their accounts leading to inactive or dormant accounts. Ramada (2012) argues that as mobile money issuers involve licensed banks, there is a strong link between mobile money and the traditional financial system, since mobile money is fully embedded within the traditional banking sector. Thus, mobile money may alleviate problems of low usage of formal financial instruments by acting as a complement deposit instrument for already formal account owners. Therefore, increasing individuals' access to mobile money may help individuals build strong resilience by providing them additional secure means of deposits and enhance their livelihood strategies (Dermish et al., 2012; Dupas and Robinson, 2013a; Ky et al., 2018; Morawczynski, 2009; Shem et al., 2012).

For the purpose of this paper, it is worthwhile to distinguish banks from credit unions for at least two reasons: first, the network of bank branches is concentrated in urban areas and mainly serves individuals with high and regular income as it is costly to collect small and irregular income through physical infrastructure (Dermish et al., 2012). By contrast, credit union institutions' coverage is often comparatively large and mainly target disadvantaged individuals or those located in remote areas. In this context, we may assume that the use of mobile money affects differently 
the way individuals use their credit union or banking accounts depending on their demographic and socioeconomic characteristics. Secondly, while there is no link between the mobile money account and credit union account, the issuers of mobile money services are licensed banks (RamadaSarasola, 2012). Mobile money is therefore fully-embedded within the banking services sector although the mobile money account is managed by a third party; usually mobile network operators. The possibility of already-banked individuals to make transactions between their mobile money account and their banking account may increase their likelihood to make deposits using their banking account (Munyegera and Matsumoto, 2016). Consequently, mobile money account appears as a complement of the bank deposit account (Allan et al., 2013; Demirgüç-Kunt et al., 2013; Karlan et al., 2014; Morawczynski, 2009; Triki and Faye, 2013). However, Morawczynski (2009) shows that some individuals may not use mobile money as a deposit account because they already have access to and use other deposit mechanisms (a bank account for example) that meet their needs. In addition, some banked individuals may find mobile money account to be inappropriate for big deposits, and others may want to build a relationship with the bank to access credit in the future. Thus, its effects may be less or null on the behavior of individuals who already have access to a bank deposit account.

\subsection{Mobile money and usage of informal deposit mechanisms}

Informal deposit instruments refer to rotating savings and credit associations (ROSCA) ${ }^{2}$, deposits at home or under mattress, with a neighbor, in livestock or pay deposits collectors (Banerjee and Duflo, 2007). While important in the lives of the poor, they are highly risky and unregulated (De Koker and Jentzsch, 2013). Christen and Mas (2009) show that the diversity of informal mechanisms that people use to manage their finances occurs because they are often subject to substantial risk of loss or theft, and their availability and liquidity are highly correlated with people's circumstances. They also argue that individuals are ready to pay small fees for remote electronic transactions which are more costly through informal channels. In the same vein, Economides and Jeziorski (2016) provide evidence showing that individuals are willing to pay and use mobile money as they perceive it to be more secure than informal storage of money. Dias and Mckee (2010) highlight that the benefit of mobile money far outweighs the risks and usually reduces important shortcomings associated with informal providers, such as loss of participants' 
funds or services' discontinuity. Therefore, we assume that individuals may use mobile money as a substitute of informal deposit mechanisms because mobile money is personal, allows individuals to access a safe deposit account and to perform financial transactions at relatively low costs and more securely.

Nevertheless, the fact that most of the poor resort to informal mechanisms to manage their finances implies that they may exhibit some advantages (Kendall, 2010). In fact, informal financial mechanisms are usually predominant in areas where formal ones are scarce. In addition, informal mechanisms (saving groups particularly) are social organizations formed to help members save for specific purposes (Chowa et al., 2012). It is also important to note that individuals are likely to use a combination of different deposit mechanisms to manage their incomes and to meet their financial needs (Gash and Gray, 2015; Kendall, 2010; De Koker and Jentzsch, 2013). Participants in informal financial mechanisms may combine informal deposit vehicles (savings groups for instance) considered appropriate when planning for long-term objectives with mobile money that is believed to be safe and convenient for short-term deposits ${ }^{3}$ or to face unpredictable life events. Hence, mobile money may be used in addition to informal financial mechanisms specially to cater to short-term financial needs.

\subsection{Mobile money and disadvantaged individuals' access to deposit mechanisms}

Considerations such as gender, geographic isolation or low population density, documentation requirement, and the high cost of formal financial services play an important role in explaining the low access to formal finance in developing countries (Allen et al., 2014; Beck et al., 2009; Demirgüç-Kunt and Klapper, 2012). The unbanked individuals are more likely to be those with low and irregular incomes, those who live in rural areas far from formal financial institutions, or socially excluded like women and less educated. Aterido et al., (2013) use household surveys across nine Sub-Saharan African countries and show that while there is no evidence for women and rural, high income and education are positively related to the use of formal banking services. They also find positive relationship between women, income and the use of informal financial services while they do not find consistent relationship between rural, education and the use of informal financial services. Mobile money is described as an instrument that allows excluded individuals from the formal financial system to perform financial transactions relatively cheaply, 
securely and reliably (Demirguc-kunt and Klapper, 2012; Dermish et al., 2012; Mbiti and Weil, 2016). Moreover, Mothobi and Grzybowski (2017) provide evidence that individuals living in poor infrastructure areas are more likely to rely on mobile money than those living in areas with better infrastructure. In this perspective, mobile money could serve as a stepping stone into the use of formal financial services. Deposits can help smooth low and irregular income patterns and meet individuals' spending objectives such as school fees and health expenses. For people who make deposits through informal methods, money security is often a challenge because the manager who collects all members' contributions can be subject to loss or theft, for instance. Thus, the need for the safety offered by mobile money innovation is essential. As mobile money provides individuals with a free electronic account that allows them to deposit money, it could be considered as a springboard to the path to formal financial inclusion.

To sum up, the above discussion leads to the following research question: How mobile money may affect the usage of the formal and informal deposit instruments? To answer this question, we identify three hypotheses that our paper aims to test:

H1: Mobile money users are more (less) inclined to make deposits using formal (informal) financial instruments than non-mobile money users.

H2: Mobile money increases formal deposits for participants in informal mechanisms.

H3: Mobile money increases formal deposits for disadvantaged people (those with low or irregular incomes, located in rural areas, women or less educated).

\section{Financial access strands and data collection}

\subsection{Background on mobile money, formal and informal systems in Burkina Faso}

Burkina Faso is one of the poorest countries in Sub-Saharan Africa, with a GDP per capita at around 761 USD and with $44.6 \%$ of the population living on less than $\$ 2 /$ day international poverty line (Gash and Gray, 2015). Access to formal financial services in Burkina Faso, as in most low-income countries, remains limited. In fact, formal and informal financial mechanisms co-exist in the country. While growing, the formal systems remain largely dominated by the informal sector as most of the population access financial services from it (Gash and Gray, 2015). The formal 
financial sector is still in its infancy and comprises of 13 commercial banks, and 4 financial societies including insurance, lending and leasing institutions. The network of bank branches that consists of around 244 branches and 305 ATM (BCEAO, 2014) is concentrated in urban areas and mainly serves individuals with high and regular income. The sizeable part of population that relies on informal deposit mechanisms represents an opportunity for formal financial intermediaries. In this context, decentralized financial systems (DFS) or microfinance institutions including credit unions, post offices and cooperatives play an important role in providing excluded individuals with financial services such as deposit accounts, loans, insurances and financial transactions including payments, pensions and money transfers. They represent an important channel for mobilizing individual savings and for reaching the excluded from the banking sector especially small/medium enterprises and disadvantaged individuals with tools of deposits and facilities to access credit (Gash and Gray, 2015; Nair and Kloeppinger-Todd, 2007; Thieba, 2013). There are around 64 decentralized financial systems ${ }^{4}$ with 285 main agencies and 349 sub-agencies throughout the country (AP/SFD-BF, 2014).

All these formal financial institutions (banks and decentralized financial institutions) are monitored and supervised by the Central Bank (BCEAO) and the Ministry of Economy and Finances through State Treasury. According to the Global Findex ${ }^{5}$ (Demirguc-Kunt et al., 2015) around 13\%of population in Burkina Faso have an account at formal financial institutions. It also reports that while $51 \%$ declare to have saved in the past years only $9 \%$ did it in formal financial institutions compared to $42 \%$ who used informal mechanisms of which $18 \%$ saved using a savings club or a person outside the family. This report illustrates the predominance of the informal mechanisms in the country.

To promote financial inclusion in the WAEMU, of which Burkina Faso is one of the eight member countries, the BCEAO cheered several initiatives ${ }^{6}$ that aim to take advantage of the opportunities of new technologies, such as promoting the use of electronic money. Thus, the Central Bank allows the entrance in the banking system of new players such as issuers of electronic money and especially mobile network operators in partnership with banks to offer mobile money services. The Central Bank provides agreement for the activity of mobile money to banks and electronic money issuers. In Burkina Faso, there are two mobile money services: "Airtel Money" launched in 2012 by the licensed bank EcoBank-Burkina in partnership with Airtel, a mobile 
operator, and "MobiCash" launched in 2013 by the licensed bank BICIAB in partnership with the mobile operator Telmob. The subscription to mobile money services requires people to have a SIM card of the mobile operator and a national ID card. Although there is no fee to access mobile money account, an initial deposit of 500 FCFA (about \$1 US) is required. Individuals owning a mobile money account have the possibility to link it to their bank account (in the respective licensed banks) that pays interest on account balances. All the electronic money issued has a counterparty of the same value held in a "trust" account at the licensed bank for the security of mobile money owners. Since the launch of mobile money, the takeoff remained modest with only around $5 \%$ of users in the adult population (as of 2014). This is consistent with Mas and Porteous (2015) who stress that rapid takeoff may not be the norm, overcoming customer caution and resistance to change requires time and experimentation. The network of mobile money agents, that insures the conversion of mobile money into cash and vice versa, has expanded since the launch of mobile money services from 483 in 2012 to 3,688 in 2014 (IMF, 2015).

\subsection{Data collection and summary statistics}

\section{Data collection methodology}

We use hand-collected data from a survey that we designed and conducted in May 2014 that consists of 500 randomly selected individuals across the central region of Burkina Faso. The country has 13 regions of which the central region is the most populated. Due to budgetary constraints, our sample frame only covers the central region which is divided into one urban municipality with 12 districts and six rural municipalities with 172 districts. The survey location is determined on the basis of the following criteria: the first is the existence of at least one formal financial institution into retained municipalities -which we check through the national institute of statistics and demography (INSD) of Burkina Faso report on financial institutions. ${ }^{7}$ The second criterion is the availability of mobile phone services that we assess through the availability of mobile operator signal. The sample frame, the central region, consists of one urban municipality, "Ouagadougou", and six rural municipalities among which only four have at least one formal financial institution. We then select among the four, one municipality that is "Saaba" . We finally choose two districts for each municipality: two urban districts in Ouagadougou and two rural districts in Saaba. For the purpose of the study, the target sample is composed of $50 \%$ of mobile 
money users that allows us to capture the effect of mobile money on the choices of deposit instruments made by users compared to non-users. Ky et al. (2018) provide a detailed description on how respondents of the survey are randomly selected in each municipality and of the survey administration methodology. At the end of the survey, our sample consisted of $405^{9}$ respondents with $50.5 \%$ of mobile money users and $49.5 \%$ of non-users.

\section{Summary statistics}

The descriptive analysis (Table 1) of the choices of deposit instruments reveals that $49 \%$ of individuals make deposits in a credit union account, $42 \%$ participate in informal deposit mechanisms, $40 \%$ use a bank account and 40\% use their mobile money account. Regarding the gender, female respondents are less likely to use bank and mobile money accounts to make deposits compared with their male counterparts (respectively $34 \%$ and $37 \%$ vs $46 \%$ and $44 \%$ ). Yet, women are more engaged in informal mechanisms for deposits with about 55\% compared to $29 \%$ of men stressing out their comparative disadvantage to access formal financial account for deposits. Similarly, less educated individuals have comparatively low access to bank and mobile money accounts (with respectively $19 \%$ and $34 \%$ vs. 55\% and $45 \%$ for highly educated individuals). According to the living place, individuals located in rural areas are less likely to make deposits in bank accounts (only 33\% of the respondents compared to the $47 \%$ for urban) possibly because bank institutions are more concentrated in urban areas. However, as alternative to bank institutions, credit unions and mobile money are more accessible due to their availability in remote areas across the country (with respectively $50 \%$ and $47 \%$ for rural vs. $49 \%$ and $34 \%$ for urban).

Taking into account mobile money usage, $47 \%$ of users reported to make deposits in a bank account compared to $33 \%$ of non-users. Conversely, the proportion of mobile money users who make deposit in informal mechanisms is lower than that of non-users (respectively $36 \% \mathrm{vs} .48 \%$ ). Expectedly, participants in informal mechanisms have lower access to bank and mobile money accounts respectively with $30 \%$ and $32 \%$ (compared to non-participants with $49 \%$ and $48 \%$ ), while they are more inclined to use a credit union account (54\% compared to $46 \%$ for non-participants). Among respondents located in rural areas, $47 \%$ use mobile money for deposits while only $34 \%$ of those located in urban areas do so. By contrast, we find that the use of informal deposits mechanisms is more common in urban than rural areas. This may stem from the fact that in urban 
areas people are more likely to get stable and predictable income than in poor rural areas. The data show that among individuals living in urban areas $62 \%$ participated in informal deposits mechanisms compared to $24 \%$ of individuals living in rural areas. Income level and type also drive some differences in the choices of deposit instruments. Across deposit instruments considered, there are around $22 \%$ of low income ${ }^{10}$ compared to $57 \%$ of high income individuals who use a bank account and $34 \%$ compared to $47 \%$ for a mobile money account. We also notice that low income individuals rely more heavily on informal mechanisms to make deposits (53\% vs. 32\%) while those with unpredictable income are less reliant on bank account (25\% vs. 54\%).

Considering the combination of deposit instruments, our statistics reveal that among individuals who make deposits using a bank account, 51\% have a credit union account, 49\% have a mobile money account and 33\% participate in informal financial mechanisms. Moreover, individuals who use a credit union account to make deposits tend to be comparatively more involved in informal financial mechanisms (48\%) than using a mobile money account (43\%) or a bank account (41\%). Among individuals who use informal deposit mechanisms, a large part has a credit union account $56 \%$, while only $34 \%$ have a mobile money account and $31 \%$ a bank account. Finally, depositors in a mobile money account are comparatively more formally included individuals with 53\% having a credit union account, 48\% a bank account and only 35\% deposit in informal mechanisms.

Overall, the reported statistics highlight far-reaching heterogeneity in the choices of deposit instruments according to individuals' characteristics and their use or not of mobile money. These observed differences motivate our empirical strategy that analyzes the effect of mobile money on the choices of deposit instruments either formal or informal by controlling individuals' characteristics. 
Table 1. Data sample characteristics: choices of deposit instruments.

\begin{tabular}{|c|c|c|c|c|c|c|}
\hline & \multirow{2}{*}{$\begin{array}{c}\text { Full } \\
\text { sample }\end{array}$} & \multirow{2}{*}{$\begin{array}{c}\text { Mobile } \\
\text { money users }\end{array}$} & \multicolumn{4}{|c|}{ Deposit instruments } \\
\hline & & & Bank & Credit union & Informal & Mobile money \\
\hline Full sample & & $50 \%$ & $40 \%$ & $49 \%$ & $42 \%$ & $40 \%$ \\
\hline \multicolumn{7}{|l|}{ Gender } \\
\hline Female & $49 \%$ & $50 \%$ & $34 \%$ & $52 \%$ & $55 \%$ & $37 \%$ \\
\hline Male & $51 \%$ & $51 \%$ & $46 \%$ & $48 \%$ & $29 \%$ & $44 \%$ \\
\hline \multicolumn{7}{|l|}{$\underline{\text { Marital situation }}$} \\
\hline Married & $48 \%$ & $57 \%$ & $48 \%$ & $54 \%$ & $38 \%$ & $48 \%$ \\
\hline Single & $51 \%$ & $44 \%$ & $32 \%$ & $45 \%$ & $50 \%$ & $33 \%$ \\
\hline At least one person in charge & $52 \%$ & $55 \%$ & $44 \%$ & $53 \%$ & $46 \%$ & $45 \%$ \\
\hline \multicolumn{7}{|l|}{$\underline{\text { Age }}$} \\
\hline$<30$ & $51 \%$ & $48 \%$ & $31 \%$ & $47 \%$ & $52 \%$ & $37 \%$ \\
\hline$>=30$ & $49 \%$ & $52.50 \%$ & $50 \%$ & $52 \%$ & $32 \%$ & $44 \%$ \\
\hline \multicolumn{7}{|l|}{$\underline{\text { Education level }}$} \\
\hline Less than secondary education level & $42 \%$ & $44 \%$ & $19 \%$ & $49 \%$ & $44 \%$ & $34 \%$ \\
\hline At least secondary education level & $58 \%$ & $55 \%$ & $55 \%$ & $50 \%$ & $41 \%$ & $45 \%$ \\
\hline \multicolumn{7}{|l|}{$\underline{\text { Living place }}$} \\
\hline Rural & $52 \%$ & $57 \%$ & $33 \%$ & $50 \%$ & $24 \%$ & $47 \%$ \\
\hline Urban & $48 \%$ & $43 \%$ & $47 \%$ & $49 \%$ & $62 \%$ & $34 \%$ \\
\hline \multicolumn{7}{|l|}{ Occupation/employment status } \\
\hline Paid activity & $81 \%$ & $48 \%$ & $41 \%$ & $52 \%$ & $42 \%$ & $38 \%$ \\
\hline Unpaid activity & $16 \%$ & $59 \%$ & $43 \%$ & $43 \%$ & $46 \%$ & $52 \%$ \\
\hline \multicolumn{7}{|l|}{ Income level and type } \\
\hline Income ranging from 10,000 to $50,000 \mathrm{FCFA}$ & $49 \%$ & $45 \%$ & $22 \%$ & $43 \%$ & $53 \%$ & $34 \%$ \\
\hline Income more than 50,000 FCFA & $51 \%$ & $55 \%$ & $57 \%$ & $56 \%$ & $32 \%$ & $47 \%$ \\
\hline Irregular income & $48 \%$ & $53 \%$ & $25 \%$ & $57 \%$ & $40 \%$ & $44 \%$ \\
\hline Regular income & $52 \%$ & $48 \%$ & $54 \%$ & $43 \%$ & $44 \%$ & $38 \%$ \\
\hline \multicolumn{7}{|l|}{ Informal mechanisms } \\
\hline Participants & $45 \%$ & $43 \%$ & $30 \%$ & $54 \%$ & $83 \%$ & $32 \%$ \\
\hline Non-participants & $55 \%$ & $57 \%$ & $49 \%$ & $46 \%$ & l & $48 \%$ \\
\hline \multicolumn{7}{|l|}{ Usage of mobile technology } \\
\hline Mobile phone user & $99 \%$ & $50 \%$ & $40 \%$ & $50 \%$ & $42 \%$ & $41 \%$ \\
\hline MM user & $50 \%$ & l & $47 \%$ & $50 \%$ & $36 \%$ & $79 \%$ \\
\hline Non-MM user & $50 \%$ & l & $33 \%$ & $49 \%$ & $48 \%$ & l \\
\hline \multicolumn{7}{|l|}{$\underline{\text { Using deposit account }}$} \\
\hline Formal & $89 \%$ & $52 \%$ & $58 \%$ & $72 \%$ & $37 \%$ & $44 \%$ \\
\hline Bank & $40 \%$ & $58 \%$ & I & $51 \%$ & $33 \%$ & $49 \%$ \\
\hline Credit union & $49 \%$ & $50 \%$ & $41 \%$ & I & $48 \%$ & $43 \%$ \\
\hline Informal & $40 \%$ & $43 \%$ & $31 \%$ & $56 \%$ & I & $34 \%$ \\
\hline Mobile money & $42 \%$ & $98 \%$ & $48 \%$ & $53 \%$ & $35 \%$ & l \\
\hline
\end{tabular}




\section{Model specification and endogeneity issue}

\subsection{Baseline model specification}

We examine the relationship between mobile money usage and individuals' choices of deposit instruments by using a logistic model specified as follows:

$$
\operatorname{PROB}\left\{y_{i}=1\right\}=\Phi\left(\alpha_{1}+\alpha_{2} \text { MMuser }_{i}+\alpha_{3} X_{i}\right)
$$

where $\Phi$ is the cumulative distribution function of logistic distribution.

In the model (1), $y_{i}$ stands for our dependent variable that characterizes individuals' choices of deposit ${ }^{11}$ instruments. It is a dummy variable that alternatively stands for deposit using: formal $^{12}$ instruments, a bank account, a credit union account, informal mechanisms or a mobile money account. These dependent variables, except deposit using formal instruments, are measured using the following questions: "During the past 12 months, did you make deposits using a bank account?"; "a credit union account?"; "informal mechanisms?”; “a mobile money account?” All these variables ${ }^{13}$ are dummies and each variable takes the value one if respondent reports YES, and zero otherwise. MMuser ${ }_{i}$ is the independent variable of interest that stands for the use of mobile money. It is a binary variable that takes the value one if the respondent indicates using mobile money, and zero otherwise. $X_{i}$ represents the set of variables controlling for age, marital situation, location, gender, occupation or employment status, at least one person in charge, education level, level and type of income.

If mobile money users are more (less) likely to make deposits using a given deposit instrument -formal and/or informal- than non-users, the coefficient $\alpha_{2}$ should be positive (negative) and statistically different from zero implying that mobile money acts as a complement (substitute) of this deposit instrument.

\subsection{Mobile money and deposit behavior of participants in informal mechanisms}

To investigate whether the use of mobile money increases the likelihood of participants in informal mechanisms to make deposits in formal financial institutions, we modify our equation (1) by including interaction terms as follows: 


$$
\operatorname{PROB}\left\{y_{i}=1\right\}=\Phi\left(\beta_{1}+\beta_{2} \text { MMuser }_{i}+\beta_{3} \text { PIM }_{i}+\beta_{4} \text { MMuser }_{i} \times \text { PIM }_{i}+\beta_{5} P_{I} M_{i} \times X_{i}+\beta_{6} X_{i}\right)
$$

where $\Phi$ is the cumulative distribution function of logistic distribution.

In the model (2), $y_{i}$ is our three dummy dependent variables that characterize individuals' choices of formal deposit instruments that alternatively stands for deposit using: formal instruments, a bank account or a credit union account ${ }^{14}$. MMuser ${ }_{i}$ represents the use of mobile money. $P I M_{i}$ is a binary variable that stands for participating in informal mechanisms. We

measure this variable using the following question: "During the past 12 months, did you use informal financial deposit mechanisms? "It takes the value one when the individual's response is YES, and zero otherwise. $X_{i}$ is the same vector of control variables used in equation (1) that we also interact with the participation in informal deposit instruments. The estimate of main interest is given by the total effect: $\beta_{2}+\beta_{4}{ }^{15}$.

\subsection{Mobile money and deposit behavior of disadvantaged individuals}

To study the effects of mobile money on the barriers to formal financial access, we consider the following individuals' characteristics: level and type of income of poor people (low and unpredictable income/high and regular income), remoteness or lack of formal financial infrastructures (rural/urban), gender discrimination (women/men) and lack of financial literacy (less educated/highly educated) ${ }^{16}$.

With regard to this investigation, we test whether mobile money affects the usage of formal and informal deposit instruments by disadvantaged individuals and how it can be considered as a springboard toward formal financial services. Since we are interested now about individuals' characteristics, we write our specification as follows:

$$
\operatorname{PROB}\left(y_{i}=1\right)=\Phi\left(\gamma_{1}+\gamma_{2} \text { MMuser }_{i}+\gamma_{3} D_{i}+\gamma_{4} \text { MMuser }_{i} \times D_{i}+\gamma_{5} D_{i} \times X_{i_{i}^{\prime}}+\gamma_{6} X^{\prime}{ }_{i}\right)
$$

where $\Phi$ is the cumulative distribution function of logistic distribution.

Where $D_{i}$ is a dummy variable that stands alternatively for individuals' characteristics that we use to examine the effects of mobile money on deposits using formal financial instruments 
taken as a whole as well as bank and credit union accounts considered separately for low vs. high income, irregular vs. regular income, rural vs. urban, women vs. men, and less vs. highly educated individuals. $X_{i}^{\prime}$ is our vector of controls from which we remove individuals' characteristics considered for the dummy $D_{i}$. The estimates of main interest are $\gamma_{2}$ and the total effect $\gamma_{2}+\gamma_{4}$.

\subsection{Endogeneity issue}

From our equations ( 1 to 3 ), to identify the effects of the use of mobile money on individuals' choices of deposit instruments we must assume that MMuser $r_{i}$ is independent of the control variables included in the regressions. Therefore, the estimated coefficients are valid only if the use of mobile money is not correlated with the error term. However, making deposits in any financial instruments considered in our analysis may be related to the decision of individuals to use mobile money. For instance, banked individuals may use mobile money with the intention to easily make deposits in their bank account, while unbanked people may use it because of lack of convenient ways to make deposits. To address this potential endogeneity issue resulting from simultaneous effects, we resort to an instrumental variable (IV) linear probability model (LPM) approach. We follow previous literature (Jack and Suri, 2014) and use the distance to the closest agent as an excluded instrument for the use of mobile money. We evaluate this distance by using the answer to the following question: "What distance did you travel to reach a mobile money agent?" The responses are encoded on a 5-point Likert scale, 1 (less than $1 \mathrm{~km}$ ), 2 (1 to $2 \mathrm{~km}$ ), 3 ( 2 to $5 \mathrm{~km}$ ), 4 (5 to $10 \mathrm{~km}$ ) and 5 (more than $10 \mathrm{~km}$ ). The underlying hypothesis of this instrument is that access to mobile money agents is required for cash in/out functions that allows for an effective use of mobile money and is not correlated with individuals' characteristics that could affect saving for specific purposes (see Table A.6 in the Appendix).

The exogeneity of the distance to the nearest mobile money agent relies on that it may not be correlated with individuals' characteristics that could affect the choice of deposit instrument. This is indeed the case as in Burkina Faso, mobile money agents are mainly composed of retail outlets (shopkeepers or small businessmen) who start mobile money business on top of their existing business in order to diversify their services and incomes. Importantly, these retail agents are often located in remote areas near the poor households. Although mobile money operators (and 
partner bank branches) have their own mobile money agents who are more likely to be located near places where there are income generating activities, the cost of installation is such that mobile money providers may favor the retail outlets. In the same vein, Munyegera and Matsumoto (2016) show that the decision of mobile money providers for licensing an agent is related to the prescribed requirements regardless of the geographical and socio-economic characteristics of the agent's location. In all cases, given that the network of mobile operators covers around $80 \%$ of the country (GSMA, 2015), mobile money services are offered in low income areas as well. We find as expected the coefficient of this variable distance to have a negative sign as the further individuals are from mobile money agents, the harder it will be to access mobile money services, and this may reduce adoption/usage of mobile money (we do not present first-stage regressions to save space). From Tables 5 to 8 we show the Kleibergen-Paap F statistic along with the corresponding StockYogo critical values at $10 \%$ for the relevance of the instrument.

In further investigations, we use the matching approach that allows to evaluate the average effect of treatment (mobile money) on our dependent variables (outcomes) by comparing individuals who receive the treatment (MMuser $=1$ ) to those who do not receive the treatment $($ MMuser $=0)($ Heckman, Ichimura and Todd, 1998; Lin, 2018). The average treatment effect on the treated (ATT) is given by the difference of the two values of the outcome:

$A \mathrm{TT}=\left(\mathrm{Y}_{1 \mathrm{i}}-\mathrm{Y}_{0 \mathrm{j}}\right)$. Where $Y_{1 i}$ is the outcome of individual $\mathrm{i}$ who uses mobile money, and $Y_{0 i}$ is the counterfactual value that gives individual i's outcome when he does not use mobile money This value is unobservable and hence it is approximated using the outcome of individuals who did not use mobile money $Y_{0 j}$. For the matching method, the statistical independence of $\left(Y_{1 i}, Y_{0 j}\right)$ and MMuser, conditional on $\mathrm{X}$ must be satisfied. Therefore, we perform a balance test that suggests no difference between treated and the control groups. The results are reported in Table A.7 in the Appendix and could be provided in an online Appendix if pressed for space. 
Table 2. Definitions of variables.

\begin{tabular}{|c|c|c|c|}
\hline Variable & Definition & Obs. & Mean \\
\hline Mobile money user (MM user) & $\begin{array}{l}\text { Reply to the question: Do you use mobile money services? Encoded as yes } \\
=1, \text { no }=0\end{array}$ & 405 & 0.50 \\
\hline $\begin{array}{l}\text { Deposit using mobile money } \\
\text { account }\end{array}$ & $\begin{array}{l}\text { Reply to the question: During the past } 12 \text { months, did you deposit your } \\
\text { money using your mobile money account? Encoded as yes }=1 \text {, no }=0\end{array}$ & 401 & 0.41 \\
\hline $\begin{array}{l}\text { Deposit using formal financial } \\
\text { institutions }\end{array}$ & $\begin{array}{l}\text { Indicate when respondents deposit their money using formal financial } \\
\text { institutions, encoded as (deposit using banks and/or credit unions) }=1 \text {, } \\
\text { others }=0\end{array}$ & 402 & 0.69 \\
\hline Deposit using bank account & $\begin{array}{l}\text { Reply to the question: During the past } 12 \text { months, did you deposit your } \\
\text { money using a bank account? Encoded as yes }=1, \text { no }=0\end{array}$ & 402 & 0.40 \\
\hline Deposit using credit union account & $\begin{array}{l}\text { Reply to the question: During the past } 12 \text { months, did you deposit your } \\
\text { money using a credit union account? Encoded as yes }=1, \text { no }=0\end{array}$ & 402 & 0.50 \\
\hline Deposit using informal mechanisms & $\begin{array}{l}\text { Reply to the question: During the past } 12 \text { months, did you deposit your } \\
\text { money using informal mechanisms? Encoded as yes }=1 \text {, no }=0\end{array}$ & 402 & 0.42 \\
\hline $\begin{array}{l}\text { Participating in informal } \\
\text { mechanisms }\end{array}$ & $\begin{array}{l}\text { Reply to the question: During the past } 12 \text { months, did you participate in } \\
\text { informal mechanisms? encoded as yes }=1, \text { no }=0\end{array}$ & 402 & 0.45 \\
\hline \multicolumn{4}{|l|}{ Individuals' characteristics } \\
\hline Age & Indicate the age of respondent & 404 & 30.55 \\
\hline Male & Indicate the gender of respondent, Encoded as Male $=1$, Female $=0$ & 405 & 0.51 \\
\hline Married & $\begin{array}{l}\text { Indicate the marital situation of respondent, Encoded as Married }=1 \text {, } \\
\text { Single }=0\end{array}$ & 405 & 0.48 \\
\hline At least one person in charge & $\begin{array}{l}\text { Indicate if the respondent has or has not dependent, Encoded as Having } \\
\text { dependent }=1 \text {, otherwise }=0\end{array}$ & 401 & 0.53 \\
\hline Education & $\begin{array}{l}\text { Indicate the education level of respondent, Encoded as Illiterate }=1 \text {, } \\
\text { Primary }=2, \text { Secondary }=3 \text {, University }=4\end{array}$ & 402 & 2.67 \\
\hline Rural & Indicate the location of respondent, Encoded as Rural $=1$, Urban $=0$ & 405 & 0.52 \\
\hline Occupation & $\begin{array}{l}\text { Indicate the employment status of respondent, Encoded as (Employed, } \\
\text { Entrepreneur, Merchant, Farmer })=1,(\text { Unemployed, Student })=0\end{array}$ & 391 & 0.84 \\
\hline Income & $\begin{array}{l}\text { Indicate the monthly income of respondent, encoded as Less than } 10,000 \\
\mathrm{FCFA}=1,10,000 \text { to } 50,000 \mathrm{FCFA}=2,50,000 \text { to } 150,000 \mathrm{FCFA}=3 \text {, } \\
150,000 \text { to } 300,000 \mathrm{FCFA}=4,300,000 \text { to } 500,000 \mathrm{FCFA}=5 \text {, More than } \\
500,000 \mathrm{FCFA}=6\end{array}$ & 405 & 2.61 \\
\hline Irregular income & $\begin{array}{l}\text { Indicate the type of income of respondent, encoded as Irregular }=1 \text {, } \\
\text { Regular }=0\end{array}$ & 403 & 0.48 \\
\hline
\end{tabular}

Instrumental variable (excluded instrument)

Distance to the nearest mobile Indicate distance to the closet mobile money agent, Encoded as less than $1 \mathrm{~km}=1,1$ to $2 \mathrm{~km}=2,2$ to $5 \mathrm{~km}=3,5$ to $10 \mathrm{~km}=4$ and more than 10 $405 \quad 2.87$ money agent $\mathrm{km}=5$

Note: Throughout, F CFA (Franc of the African Financial Community) refers to the local currency. The exchange rate during the survey period was about $500 \mathrm{~F} \mathrm{CFA}=\$ 1 \mathrm{US}$. 


\section{Results}

In the following tables, we present side by side the results of our logistic empirical specification along with those of the IV strategy obtained from the linear probability model (LPM) using 2SLS estimator (Angrist and Pischke, 2008) even if the endogeneity test ${ }^{17}$ does not reject the null hypothesis of exogeneity of mobile money use. We also provide the results from the propensity matching score (PMS) approach modelled using a logistic model (the Appendix Tables A.8 to A.10). Overall, all our conclusions are similar and therefore, we only discuss results from the logistic model. ${ }^{18}$

\subsection{Mobile money and choices of deposit instruments}

Table 3 presents estimates of the effects of the adoption of mobile money on individuals' choices of deposit instruments. As a starting point, we analyze the probability of mobile money users compared to non-users to make deposits using formal and/or informal financial mechanisms. Across the columns, we find a significant suggestive evidence of mobile money only in column 5 whereby, as one may expect, the use of mobile money is positively associated with making deposits in mobile money account. Indeed, Mbiti and Weil (2016) and Mas and Mayer (2011) description of the mobile money account emphasize that it is used to make deposits for forward payments or future purposes. Moreover, our results support the findings of Van Der Boor et al. (2014) that in developing countries poor people with fewer or without options for accessing banking services would be inclined to use mobile phones to perform financial transactions that appear to be safe, less expensive and more reliable compared to formal and informal financial alternatives. However, we find no difference in the likelihood of mobile money users compared to mobile money nonusers to make deposits in formal financial institutions (for both banks and credit unions) or using informal deposit mechanisms. Therefore, these results do not confirm our first hypothesis that users of mobile money are more (less) inclined to make deposits using formal (informal) financial instruments compared to non-users. Prior the detail of the next step of our investigation, we briefly discuss hereafter our control variables, namely the effect of socioeconomic characteristics on individuals' choices of deposit instruments. 
Starting with the variable married, we find that it is positively and significantly associated with deposit in formal instruments as a whole, in credit union and in mobile money accounts. In settings where a head of household often emigrates in search for opportunities, this result may indicate preferred deposit instruments for those working far from their families.

Considering the living place and gender, the estimates suggest that the group of individuals located in urban areas and being female facilitate the formation of informal deposit mechanism. The negative and significant coefficient associated with occupation may reflect the fact that poor individuals with unpaid activity may comparatively rely more on mobile money that is accessible and affordable to make deposits. Consistent with the distinction between banks and credit unions made earlier (section 2.1), the results show that individuals with irregular income have less inclination to make deposits in a bank account and rely rather on credit union institutions that are more expanded throughout the country. The estimates of education reveal a positive and significant association with deposits in formal financial instruments taken as a whole and using a bank account. The results for the income level (income and income squared) may indicate a hump-shape relationship between income and deposit using formal financial instruments and credit union.

\subsection{Facilitating formal deposits of participants in informal mechanisms}

We focus on participants in informal mechanisms and analyze whether the use of mobile money may facilitate their access to formal financial deposit instruments. Table 4 presents the results. We find that individuals engaged in informal mechanisms benefit from the use of mobile money. More precisely, the results show a positive relationship between the use of mobile money and making deposits in a bank account that may increase by $16 \%{ }^{19}$ (column, 2), but no relationship appears with credit union account (column 3) or formal financial institutions taken as a whole (column 1). These results support our second hypothesis and confirm the previous discussion which emphasized how the linkage between mobile money account and bank account may play a role in the choices of deposit instruments. Credit union institutions being more widespread and comparatively more accessible than banks, mobile money would be more useful to access the bank accounts than credit union accounts. Our findings also suggest that mobile money may possibly help to shift a fraction of deposits from less secure informal mechanisms to formal financial 
Table 3. Choices of deposit instruments and mobile money adoption. ${ }^{20}$

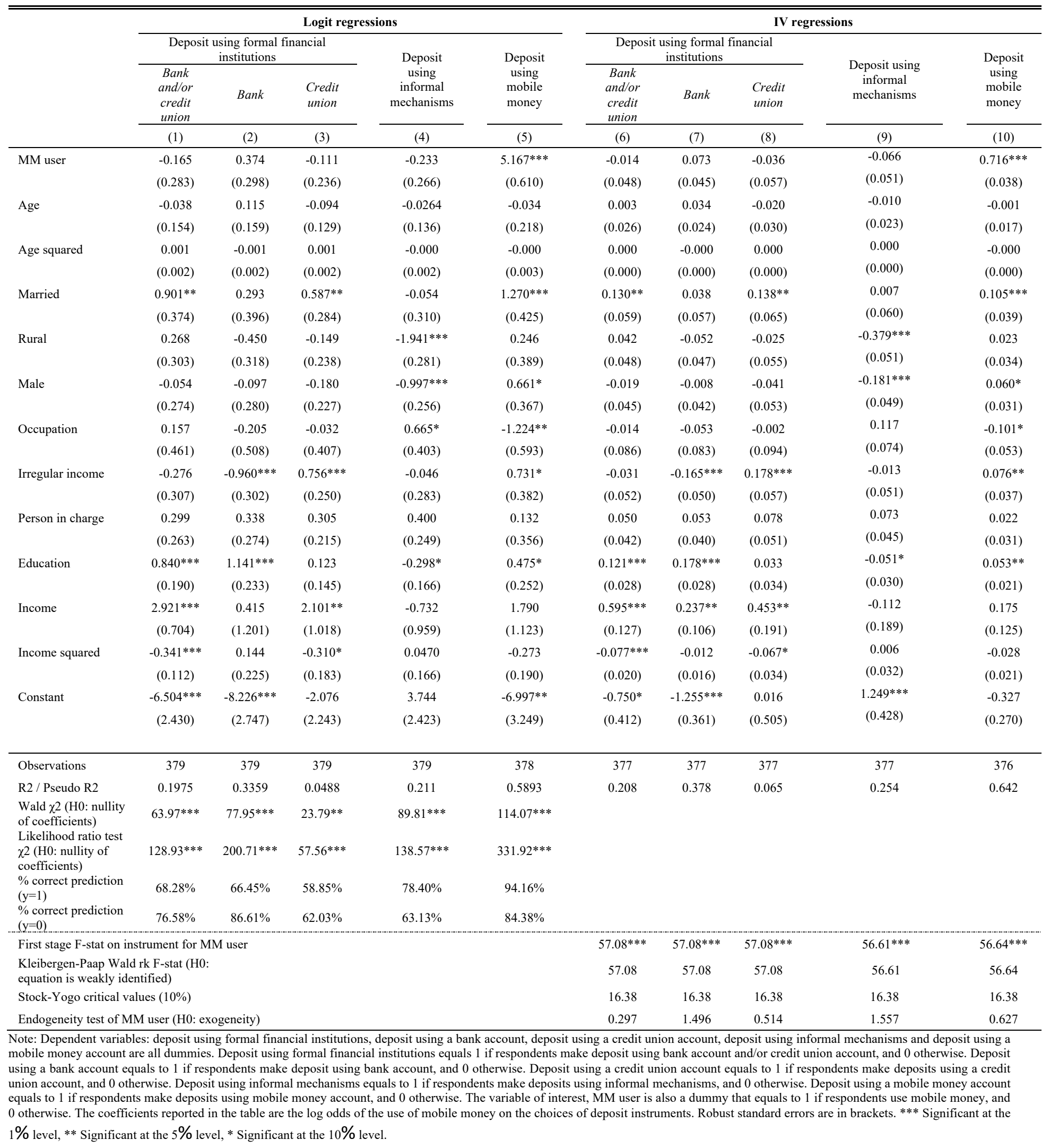


instruments. Moreover, our results are in line with Demirguc-kunt et al. (2015) who describe that shifting to digital payments, particularly mobile money can provide an important first entry point into the formal financial system. However, it is important to note that mobile money users may use it in addition to their informal financial services. To shed more light on this possible "shifting" effect, we run a regression using the response to the following question of our survey: "Did you reduce the use of informal instruments since your mobile money adoption?" We derive a dummy variable that takes the value one if the response was YES and zero otherwise. We find that the probability of participants in informal instruments, who report to have reduced their use since their adoption of mobile money, to make deposits using a bank account may increase by $9 \%$ (Table A.2 in Appendix). Accordingly, the use of mobile money seems to be strongly associated with the use of a bank account for deposits than with a credit union account as mobile money users can easily make deposits in their bank account with their mobile phone (Mas, 2010; Munyegera and Matsumoto, 2016).

\subsection{Overcoming barriers to financial access}

In Table 5A we report estimates of the effects of mobile money on the choices of deposit instruments for groups of individuals which differ by level and type of income. Considering the level of income, the results indicate that for low (high) income individuals, the use of mobile money is negatively (positively) associated with making deposits using formal financial institutions. Hence, in this case, mobile money may act as a substitute (complement) of formal deposit instruments for mobile money users with a low (high) income. These results may suggest the existence of a "threshold income" beyond which mobile money facilitates the use of formal deposit instruments. Considering the type of income, we find that the use of mobile money is positively associated with making deposits using a bank account for irregular income individuals suggesting complementarity effect between mobile money and bank accounts. This result indicates that mobile money might overcome barriers related to the unpredictable income of individuals to access a bank account while it has no effect on credit union institutions that are more expanded throughout the country. 


\section{Table 4. Choices of deposit instruments and mobile money adoption: participants in informal}

financial mechanisms.

\begin{tabular}{|c|c|c|c|c|c|c|}
\hline & \multicolumn{3}{|c|}{ Logit regressions } & \multicolumn{3}{|c|}{ IV regressions } \\
\hline & \multicolumn{3}{|c|}{ Deposit using formal financial institutions } & \multicolumn{3}{|c|}{ Deposit using formal financial institutions } \\
\hline & $\begin{array}{l}\text { Bank and/or credit } \\
\text { union }\end{array}$ & Bank & $\begin{array}{l}\text { Credit } \\
\text { union }\end{array}$ & $\begin{array}{l}\text { Bank and/or credit } \\
\text { union }\end{array}$ & Bank & $\begin{array}{l}\text { Credit } \\
\text { union }\end{array}$ \\
\hline & (1) & (2) & (3) & (4) & (5) & (6) \\
\hline \multirow[t]{2}{*}{ MM user $(\beta 2)$} & -0.432 & -0.338 & -0.222 & -0.027 & 0.010 & -0.063 \\
\hline & $(0.537)$ & $(0.415)$ & $(0.338)$ & $(0.061)$ & $(0.065)$ & $(0.080)$ \\
\hline \multirow[t]{2}{*}{ Participating in informal mechanisms } & 1.360 & $-12.17 *$ & -3.286 & 0.289 & -0.390 & -0.370 \\
\hline & $(5.794)$ & $(6.789)$ & $(5.427)$ & $(0.951)$ & $(0.797)$ & $(1.080)$ \\
\hline \multirow[t]{2}{*}{$\begin{array}{l}\text { MM user } x \text { Participating in informal } \\
\text { mechanisms }(\beta 4)\end{array}$} & 0.211 & $1.801 * * *$ & 0.0584 & -0.013 & 0.124 & 0.029 \\
\hline & $(0.682)$ & $(0.685)$ & $(0.518)$ & $(0.094)$ & $(0.088)$ & $(0.112)$ \\
\hline $\begin{array}{l}\text { Participating in informal mechanisms } \mathrm{x} \\
\text { Controls }\end{array}$ & YES & YES & YES & YES & YES & YES \\
\hline Controls & YES & YES & YES & YES & YES & YES \\
\hline \multicolumn{7}{|l|}{ Wald: } \\
\hline \multirow[t]{2}{*}{$(\beta 2)+(\beta 4)$} & -0.220 & $1.463 * * *$ & -0.163 & -0.040 & $0.134^{* *}$ & -0.034 \\
\hline & $(0.420)$ & $(0.546)$ & $(0.392)$ & $(0.071)$ & $(0.058)$ & $(0.078)$ \\
\hline Observations & 377 & 377 & 377 & 375 & 375 & 375 \\
\hline R2 / Pseudo R2 & 0.271 & 0.417 & 0.134 & 0.295 & 0.427 & 0.171 \\
\hline Wald $\chi^{2}$ (H0: nullity of coefficients) & $93.87 * * *$ & $76.88 * * *$ & $62.52 * * *$ & & & \\
\hline $\begin{array}{l}\text { Likelihood ratio test } \chi^{2} \text { (H0: nullity of } \\
\text { coefficients) }\end{array}$ & $166.40^{* * *}$ & $243.53 * * *$ & $104.64 * * *$ & & & \\
\hline$\%$ correct prediction $(\mathrm{y}=1)$ & $84.33 \%$ & $85.16 \%$ & $67.19 \%$ & & & \\
\hline$\%$ correct prediction $(\mathrm{y}=0)$ & $63.30 \%$ & $79.73 \%$ & $68.65 \%$ & & & \\
\hline \multicolumn{4}{|c|}{ First stage F-stat on instrument for MM user } & $413.86^{* * *}$ & $413.86^{* * *}$ & $413.86^{* * *}$ \\
\hline \multicolumn{4}{|c|}{ First stage F-stat (MM user x Participating in informal mechanisms) } & $551.01 * * *$ & $551.01 * * *$ & $551.01 * * *$ \\
\hline \multicolumn{4}{|c|}{ Kleibergen-Paap Wald rk F-stat (H0: equation is weakly identified) } & 8.94 & 8.94 & 8.94 \\
\hline \multicolumn{4}{|l|}{ Stock-Yogo critical values $(10 \%)$} & 7.03 & 7.03 & 7.03 \\
\hline \multicolumn{4}{|c|}{ Endogeneity test of MM user (H0: Exogeneity) } & 0.204 & 2.242 & 0.538 \\
\hline
\end{tabular}

Note: Dependent variables: deposit using formal financial institutions, deposit using bank account and, deposit using credit union account are all dummies. Deposit using formal financial institutions equals 1 if respondents make deposits using bank account and/or credit union account, and 0 otherwise. Deposit using bank account equals to 1 if respondents make deposits using bank account, and 0 otherwise. Deposit using credit union account equals to 1 if respondents make deposits using credit union account, and 0 otherwise. With the interactions, the total effect is given by the sum of the coefficient of the interaction term plus the coefficient of the use of mobile money (MM user), and the $p$-value obtained through the Wald test is reported below. The coefficients reported in the table are the log odds of the use of mobile money on the choices of deposit instruments. Robust standard errors are in brackets. ${ }^{* * *}$ Significant at the $1 \%$ level, ** Significant at the $5 \%$ level, * Significant at the $10 \%$ level. 
We turn now to the remaining set of individuals' demographic and socio-economic characteristics that appear to be obstacles to the access of formal financial deposit instruments. In Table 5B, we present the effect of mobile money on individuals' choices of deposit instruments on the basis of their location, gender and level of education. Considering the group of rural, women and less educated individuals, we find that mobile money seems to help them overcome barriers to access formal deposit instruments. The results show that mobile money may increase the probability to make deposits using a bank account by $15 \%$ for women, and using bank and credit union accounts by respectively $13 \%$ and $15 \%$ for less educated individuals ${ }^{21}$. We do not find any relationship for individuals located in rural areas, implying that mobile money account may be used in this case for deposit holdings (Table A.3 in the Appendix) instead of bank and credit union accounts. Our results indicate a complementarity effect between mobile money and bank accounts for women, while this effect concerns mobile money, bank and credit union accounts for less educated individuals. All our findings are consistent with the fact that credit union institutions are more widespread and affordable for women and less educated people than bank institutions. Although the linkage between mobile money account and bank account may lead individuals toward bank institutions, our results show that mobile money decreases low income individuals' likelihood to make deposits using formal financial institutions. These findings are consistent with those of Mothobi and Grzybowski (2017) that mobile money broadens banking services access, thereby alleviating the lack of banking infrastructure in the area where poor people live $\mathrm{e}^{22}$.

Overall, our findings (in Tables 5A and 5B) support our third hypothesis that mobile money is beneficial to disadvantaged groups (individuals with irregular incomes, women and less educated individuals) by improving their use of formal financial instruments. The results show that mobile money can transform individuals' financial behavior by helping them overcome barriers to access formal deposits instruments especially for formally excluded individuals. Consequently, mobile money appears as a stepping-stone toward formal financial institutions for disadvantaged individuals. 
Table 5A. Choices of deposit instruments and mobile money adoption: Disadvantaged people.

Logit regressions

Deposit using formal financial instituions

$\frac{\text { Deposit using formal financial institutions }}{\text { Bank and/or credit union }}$ Bank Credit union $\quad$ Deposit in informal mechanisms

MM user $(\gamma 2)$
Low income

$\begin{array}{ccc}(1) & (2) & (3) \\ 1.084^{* *} & 0.665 & 0.234\end{array}$

$(3)$
0.234
$(0.354)$

$\begin{array}{ccc}(0.514) & (0.409) & (0.354) \\ 11.017^{* *} & -2.053 & 8.509 * \\ (5.521) & (5.770) & (4.989)\end{array}$

$(5.521) \quad(5.770) \quad(4.989)$

MM user $\mathrm{x}$ Low income $(\gamma 4)$

$\begin{array}{ll}-0.642 & -0.810 \\ (0.618) & (0.509)\end{array}$

Low income $\mathrm{x}$ Controls

Controls included

YES

YES

Wald:

$(\gamma 2)+(\gamma 4)$

Observations

R2 / Pseudo R2

Wald $\chi^{2}$ (H0: nullity of coefficients)

Likelihood ratio test $\chi 2$ ( $\mathrm{H} 0$ : nullity of coefficients)

$\%$ correct prediction $(\mathrm{y}=1)$

$\%$ correct prediction $(\mathrm{y}=0)$

First stage F-stat on instrument for MM user

First stage F-stat (MM user x Low income)

Kleibergen-Paap Wald rk F-stat (H0: equation is weakly identified)

Stock-Yogo critical values $(10 \%)$

Endogeneity
Exogeneity)

IV regressions

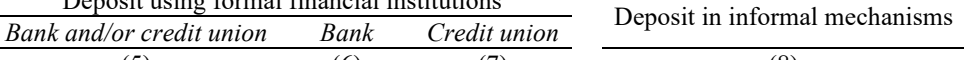

$(4)$
-0.057
$(0.432)$
$8.994 *$

(5)

$\begin{array}{ccc} & (6) & (7) \\ 0.111^{* *} & 0.132^{*} & 0.03\end{array}$

(7)

$\begin{array}{llll}(0.054) & (0.068) & (0.077) & (0.065) \\ 1.266 & 0.050 & 1.776 * & -0.557\end{array}$

$\begin{array}{llll}1.266 & 0.050 & 1.776^{*} & -0.557 \\ (0.856) & (0.886 & (1.009) & (0.790)\end{array}$

$\begin{array}{llll}(0.856) & (0.886) & (1.009) & (0.790) \\ -0.264 * * * & -0.118 & -0.143 & -0.047\end{array}$

$\begin{array}{llll}(0.095) & (0.091) & (0.113) & (0.100)\end{array}$

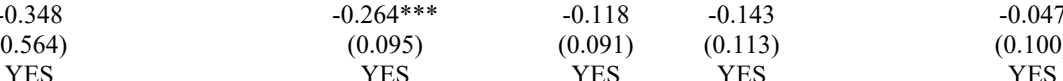

YES YES YES

$\begin{array}{ccc}-0.782 * * & 0.023 & -0.576 \\ (0.368) & (0.464) & (0.366)\end{array}$

$\begin{array}{ccc}0.379 & (0.464) & (0.366) \\ 0.220 & 379 & 379\end{array}$

$$
0.220
$$

$68.34 * * *$

$39.01 * * *$

$82.46 \%$

$0.326 \quad 0.111$

379
0.111
$46.53 * * *$
$90.09 * * *$

$\begin{array}{ll}9.51 * * * * & 46.53 * * * \\ 81.29 \% & 60.09 * *\end{array}$

$61.98 \%$

YES

YES

YES YES

YES

$-0.406$

(0.362)

379
0.267

$0.014-0.113$

$\begin{array}{cccc}-0.153^{*} & 0.014 & -0.113 & -0.092 \\ (0.079) & (0.059) & (0.082) & (0.077) \\ 377 & 377 & 377 & 377\end{array}$

$-0.092$

0.267
$598.65 * * *$

0.23

0.370

0.141

0.299

$85.80 \%$

$63.13 \%$

\begin{tabular}{cccc}
$472.01^{* * *}$ & $472.01^{* * *}$ & $472.01^{* * *}$ & $472.01 * * *$ \\
$638.08^{* * *}$ & $638.08^{* * *}$ & $638.08^{* * *}$ & $485.78^{* * *}$ \\
8.90 & 8.90 & 8.90 & 10.897 \\
7.03 & 7.03 & 7.03 & 7.03 \\
0.658 & 1.684 & 1.128 & 0.248 \\
\hline
\end{tabular}

Logit regressions

Deposit using formal financial institutions \begin{tabular}{cccc}
\multicolumn{2}{c}{ Deposit using formal financial institutions } & Deposit in informal mechanisms \\
\hline Bank and/or credit union & Bank & Credit union
\end{tabular} (1)

IV regressions

Deposit using formal financial institutions $\quad$ Deposit in informal mechanisms

\begin{tabular}{cccccc}
\hline Bank and/or credit union & Bank & Credit union & & Depsit in inforn \\
\cline { 1 - 3 }$(5)$ & $(6)$ & $(7)$ & & (8) \\
\hline 0.034 & -0.008 & 0.032 &
\end{tabular}

0.034

$\begin{array}{ccc}-0.008 & 0.032 & -0.016 \\ (0.059) & (0.079) & (0.062) \\ 1.728 * & -3.765 * *\end{array}$

$\begin{array}{ccc}-0.057 & -0.228 & 0.157 \\ (0.465) & (0.433) & (0.333) \\ -7.209 & 9.075 & -21.111^{* *} \\ (6.559) & (6.822) & (6.990)\end{array}$

Irregular income

$\begin{array}{lrr}-7.209 & (0.075 & -21.111 \\ (6.559) & (6.822) & (6.990) \\ -0.073 & 1.340 \% & -0.354\end{array}$

MM user $\mathrm{x}$ Irregular income $(\gamma 4)$

$\begin{array}{lll}-0.073 & 1.340^{*} & -0.354 \\ (0.68) & (0.69) & (0.498)\end{array}$

$\begin{array}{lll}0.608) & (0.699) & (0.498 \\ \text { YES } & \text { YES } & \text { YES }\end{array}$

Irregular income x Controls

Controls

YES YES YES

YES

YES YES

YES

$-0.130$

(0.393

Observations

R2 / Pseudo R2

Wald $\chi^{2}$ ( $\mathrm{H} 0$ : nullity of coefficients)

Likelihood ratio test $\chi 2$ (H0: nullity of coefficients)

$\%$ correct prediction $(\mathrm{y}=1)$

First stage F-stat on instrument for MM user

$(0.385)$

$\begin{array}{ll}0.444^{*} & (0.059) \\ (5.143) & -1.497\end{array}$

$\begin{array}{ll}-9.444 * & -1.497 \\ (5.143) & (0.857) \\ -0.545 & -0.078\end{array}$

$-0.545$

$(0.553)$

YES

$\begin{array}{lll}379 & (0.548) & (0.371) \\ 0.253 & 379 & 379\end{array}$

0.253

$\begin{array}{lll}71.07 * * * & 108.54 * * * & 45.18^{* * *} \\ 154.38^{* * *} & 228.23 \% & \\ 71.27 \% & 70.97 \% & 67.19 \%\end{array}$

$\begin{array}{ccc}71.27 \% & 228.23^{* * *} & 95.33^{* * *} \\ & 70.97 \% & 67.19 \%\end{array}$

$80.18 \%$

$67.19 \%$

$\begin{array}{llr}-1.497 * & & \\ (0.857) & (0.850) & (0.954) \\ -0.078 & 0.149^{*} & -0.082 \\ (0.097) & (0.087) & (0.112)\end{array}$

$\begin{array}{ll}0.149^{*} & -0.082 \\ (0.087) & (0.112)\end{array}$

$(0.062)$

$0.062)$
-1.271

YES

$(0.087) \quad(0.112)$

YES

$-0.312$

(0.397)

379
0.273

$-0.044$

$(0.077)$

YES

$-0.054$

(0.102)

YES

First stage $\mathrm{F}$

Kleibergen-Paap Wald rk F-stat (H0: equation is weakly identified)

Stock-Yogo critical values $(10 \%)$

Endogeneity test of MM user (H0:

Exogeneity)

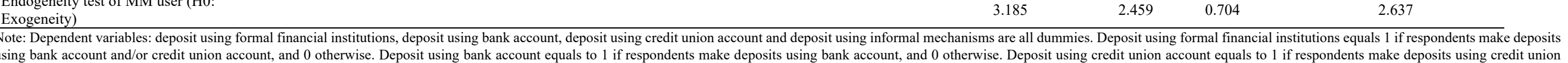

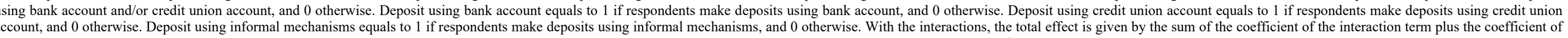

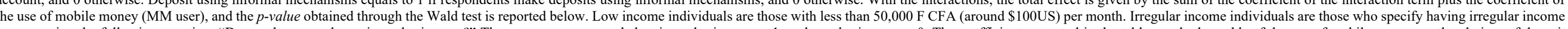

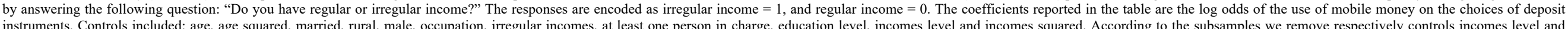
instruments. Controls included: age, age squared, married, rural, male, occupation, irregular incomes, at least one person in charge, education level, incomes level and incom
incomes squared, and irregular incomes. Robust standard errors are in brackets. ${ }^{* *}$ Significant at the $1 \%$ level, ${ }^{* *}$ Significant at the $5 \%$ level, * Significant at the $10 \% 1$ level. 


\section{Conclusion}

This paper examines the interplay between mobile money innovation and pre-existing formal and informal financial instruments, with a particular focus on its potential to enhance financial access for disadvantaged individuals. In developing countries, the predominance of informal deposit mechanisms associated with the underdeveloped formal financial system raises questions about the effect that the growing technology of mobile money may have on the improvement of financial access. The paper addresses this issue.

We use an original dataset obtained from a survey we conducted in Burkina Faso in May 2014 and find overall that the use of mobile money is not associated with deposits using formal and informal financial instruments but, as one may expect, it is positively associated with making deposits in mobile money account. By contrast and more interestingly, we show in further analysis a positive relationship between the use of mobile money by participants in informal mechanisms and deposits in formal financial instruments; bank accounts more precisely. Thus, our findings are in line with current efforts by central banks, governments and international organizations to improve financial access by encouraging the adoption of mobile money.

We also show that among disadvantaged groups, mobile money usage seems to be associated with an increase in the probability of women, individuals with irregular income and those who are less educated to make deposits using bank and credit union accounts. Our results therefore support the evidence suggesting that various socioeconomic constraints depress deposits even among those with access (Allan et al., 2013; Kendall, 2010; Kendall et al., 2011). In settings where the technology of mobile money exists, bridging the gap in individuals' access to formal financial services is not overstating. Government and policymakers may act through specific strategies to motivate mobile money providers to reach remote areas to ensure access to basic formal financial services throughout the country. Expanding mobile money agent networks by facilitating retail stores to expand mobile money businesses especially in rural areas may help reduce the gap in formal financial access between urban and rural areas. Policies that focus on and motivate women, less educated and participants of informal savings groups' access to and usage of mobile money services are well advised and should be encouraged. More specifically, promoting the creation of an informal savings groups linked to individuals' mobile money account and that allows transactions between both accounts may reduce the need of cash exchanges that is less 
Table 5B. Choices of formal deposit instruments and mobile money adoption: Disadvantaged people (Continued) Logit regressions

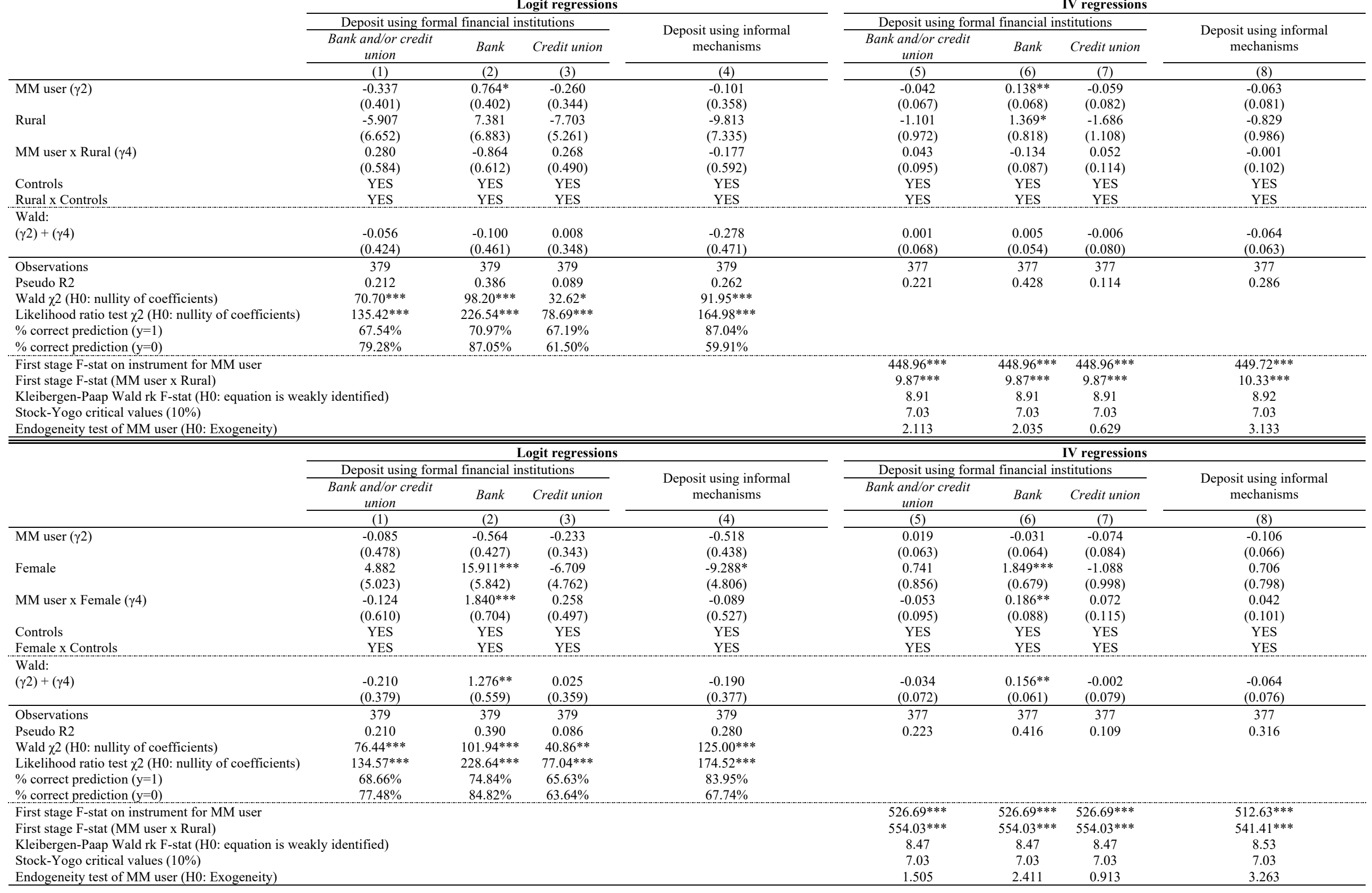


Logit regressions

Deposit using formal financial institutions

Credit union

Deposit using informal

\begin{tabular}{ccc} 
union & Bank & Credit union \\
\hline$(1)$ & $(2)$ & $(3)$ \\
\hline-0.612 & 0.574 & $-0.650^{* *}$ \\
$(0.440)$ & $(0.365)$ & $(0.323)$ \\
$9.476^{*}$ & $11.630^{*}$ & 6.083 \\
$(5.331)$ & $(6.943)$ & $(5.155)$ \\
$1.206^{* *}$ & 0.448 & $1.378^{* * *}$ \\
$(0.585)$ & $(0.674)$ & $(0.492)$ \\
YES & YES & YES \\
YES & YES & YES \\
& & \\
0.594 & $1.021 *$ & $0.727 * *$ \\
$(0.385)$ & $(0.567)$ & $(0.371)$ \\
382 & 382 & 382 \\
0.224 & 0.339 & 0.104 \\
$223.01 * * *$ & $270.09 * * *$ & $193.02 * * *$ \\
$139.58^{* * *}$ & $199.31 * * *$ & $83.01 * * *$ \\
$69.00 \%$ & $64.97 \%$ & $69.59 \%$ \\
$80.18 \%$ & $85.78 \%$ & $63.30 \%$ \\
\hline
\end{tabular}

MM user $(\gamma 2)$

MM user $\mathrm{x}$ Less educated $(\gamma 4)$

Controls

Less educated $\mathrm{x}$ Controls

Wald:

$(\gamma 2)+(\gamma 4)$

\section{Observations}

Pseudo R2

Wald $\chi 2$ (H0: nullity of coefficients)

Likelihood ratio test $\chi 2$ (H0: nullity of coefficients)

$80.18 \%$

$63.30 \%$

$\%$ correct prediction $(\mathrm{y}=0)$

First stage $\mathrm{F}$-stat on instrument for MM user

First stage F-stat (MM user x Rural)

Kleibergen-Paap Wald rk F-stat (H0:

equation is weakly identified)

Stock-Yogo critical values $(10 \%)$

Endogeneity test of MM user (H0

Exogeneity)

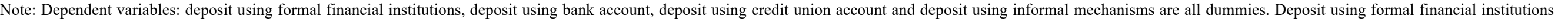

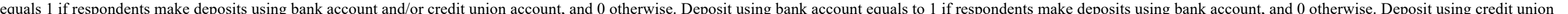

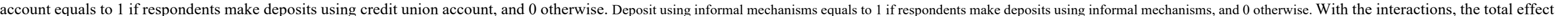

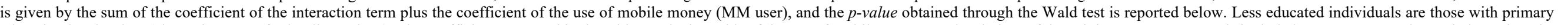

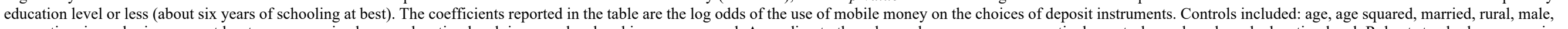

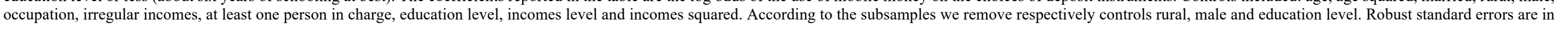
brackets. $* * *$ Significant at the $1 \%$ level, ${ }^{* *}$ Significant at the $5 \%$ level, $*$ Significant at the $10 \%$ level.
IV regressions

Deposit using formal financial institutions $\quad$ Deposit using informal

\begin{tabular}{ccccc} 
union & Bank & Credit union & & mechanisms \\
\hline$(5)$ & $(6)$ & $(7)$ & & $(8)$ \\
\hline-0.062 & 0.089 & $-0.144^{*}$ & & -0.064 \\
$(0.058)$ & $(0.058)$ & $(0.075)$ & & $(0.062)$ \\
-0.454 & $1.387^{*}$ & -0.767 & & 0.232 \\
$(0.937)$ & $(0.794)$ & $(1.044)$ & & $(0.847)$ \\
$0.185^{*}$ & 0.050 & $0.280^{* *}$ & & -0.032 \\
$(0.099)$ & $(0.089)$ & $(0.113)$ & & $(0.108)$ \\
YES & YES & YES & & YES \\
YES & YES & YES & & YES
\end{tabular}

$\begin{array}{llll}0.123 & 0.139 * * & 0.136^{*} & -0.097\end{array}$

\begin{tabular}{ccccc}
$-0.383)$ & $(0.081)$ & $(0.068)$ & $(0.084)$ & $(0.088)$ \\
\hline 382 & 377 & 377 & 377 & 377 \\
0.223 & 0.230 & 0.388 & 0.131 & 0.260
\end{tabular}

$\begin{array}{ccccc}382 & (0.081) & (0.068) & (0.084) & (0.088) \\ 0.223 & 377 & 377 & 377 & 377 \\ & 0.230 & 0.388 & 0.131 & 0.260\end{array}$

$\begin{array}{cccc}346.28^{* * *} & 346.28^{* * *} & 346.28^{* * *} & 347.47^{* * *} \\ 435.16^{* * *} & 435.16^{* * *} & 435.16^{* * *} & 431.60^{* * *} \\ 13.43 & 13.43 & 13.43 & 13.30 \\ 7.03 & 7.03 & 7.03 & 7.03\end{array}$

7.03

42.25

$78.40 \%$

$65.45 \%$ 
secure and favor electronic money. For instance, in Tanzania and Uganda mobile money products are tailored to meet the needs of saving groups allowing to reduce groups' reliance on cash and address their need for increased security, convenience and transparency (Bhandari, 2015; Helmore, 2011). A group wallet is created to safely store group funds, report all mobile transactions, and the group mobile wallet can be linked to a bank account that facilitates access to interest-bearing savings, credit, loans disturbance and repayment. Thus, mobile money may in turn bring out individuals from informal financial methods toward formal financial institutions by increasing the likelihood of individuals to access/use bank and credit union accounts. Nonetheless, our results should be interpreted with caution given the lack of information on the amount allocated to each financial instrument but further works would require quantitative and more detailed data to extend the current analysis. Similarly, while we control for potential endogeneity, future research may try to endogenize the explanatory variables by jointly modeling the decisions to use mobile money and particular financial deposit instruments. Again, this requires conducting a survey specifically suited for more structural modeling of consumer decision that we leave for future research. 


\section{Acknowledgements}

An earlier version of the paper was presented at the LAPE PhD seminars. We are grateful to Iftekar Hassan, Kose John, Philippe Rous, Ruth Tacneng, Céline Meslier, Emmanuelle Nys, and Leo Indra Wardhana for their helpful comments and suggestions. We also wish to thank Dénis Ouédraogo and Jean-Paul Ouoba from the Institut National de la Statistique et de la Démographie du Burkina Faso for providing us data on access to financial services.

We also acknowledge the fruitful comments of our discussants Louis Orozco, Tania Lopez and the participants at the 64th Annual Meeting of the French Economic Association and the 33rd International Symposium on Money, Banking and Finance. All remaining errors are naturally ours. This research did not receive any specific grant from funding agencies in the public, commercial, or not-for-profit sectors. 


\section{References}

Allan, A., Massu, M., Svarer, C., 2013. Banking on Change: Breaking the Barriers to Financial Inclusion. Barclays, Plan UK, CARE.

Allen, F., Carletti, E., Cull, R., Qian, J. "QJ," Senbet, L., Valenzuela, P., 2014. The African Financial Development and Financial Inclusion Gaps. J. Afr. Econ. 23, 614-642. https://doi.org/10.1093/jae/eju015

Ambrosius, C., Cuecuecha, A., 2015. Remittances and the Use of Formal and Informal Financial Services. World Dev. 77, 80-98.

Angrist, J.D., Pischke, J.S., 2008. Mostly Harmless Econometrics : An Empiricist 's Companion. Princet. Princet. Univ. Press. https://doi.org/10.1017/CBO9781107415324.004

Aron, J., 2017. ' Leapfrogging ': a Survey of the Nature and Economic Implications of Mobile Money. CSAE Work. Pap. WPS/2017-02.

Association Professionnelle des Systèmes Financiers Décentralisés du Burkina Faso, A.-B., 2014. Rapport d'analyse des performances financières de 2010-2012 des membres de l'AP/SFD$\mathrm{BF}$.

Aterido, R., Beck, T., Iacovone, L., 2013. Finance in Sub-Saharan Africa : Is There a Gender Gap ? World Dev. 47, 102-120.

Banerjee, A., Duflo, E., 2007. The Economic Lives of the Poor. J. Econ. Perspect. 21, 1-22. https://doi.org/10.1257/jep.21.1.141.The

Baum, C.F., Schaffer, M.E., Stillman, S., 2007. Enhanced routines for instrumental variables/generalized method of moments estimation and testing. Stata J. 7, 465-506. https://doi.org/The Stata Journal

Banque Centrale des Etats de l'Afrique de l'Ouest (BCEAO), 2014. Commission Bancaire Rapport Annuel.

Beck, T., Demirgüç-Kunt, A., Honohan, P., 2009. Access to financial services: Measurement, impact, and policies. World Bank Res. Obs. 24, 119-145. https://doi.org/10.1093/wbro/lkn008 
Beck, T., Demirguc-Kunt, A., Peria, M.S.M., 2008. Banking Services for Everyone? Barriers to Bank Access and Use around the World. World Bank Econ. Rev. 22, 397-430. https://doi.org/10.1093/wber/lhn020

Beck, T., Feyen, E., Ize, A., Moizeszowicz, F., 2008. Benchmarking Financial Development. Policy Res. Work. Pap. 4638, World Bank.

Beise, M., 2004. Lead markets: Country-specific drivers of the global diffusion of innovations. Res. Policy 33, 997-1018. https://doi.org/10.1016/j.respol.2004.03.003

Bhandari, P., 2015. Connected Women Case study Airtel Uganda: A mobile money solutions for savings groups. GSMA.

Carpenter, S.B., Jensen, R.T., 2002. Household participation in formal and informal savings mechanisms: Evidence from Pakistan. Rev. Dev. Econ. 6, 314-328. https://doi.org/10.1111/1467-9361.00157

Chowa, G., Masa, R., Sherraden, M., 2012. Wealth Effects of an Asset-Building Intervention Among Rural Households in Sub-Saharan Africa. J. Soc. Social Work Res. 3, 329-345. https://doi.org/10.5243/jsswr.2012.20

Christen, B., Mas, I., 2009. It's time to address the microsavings challenge, scalably. Enterp. Dev. Microfinance 20, 274-285. https://doi.org/10.3362/1755-1986.2009.031

Christensen, G., 1993. The Limits to Informal Intermediation. World Dev. 21, 721-731.

De Koker, L., Jentzsch, N., 2013. Financial Inclusion and Financial Integrity: Aligned Incentives? World Dev. 44, 267-280. https://doi.org/10.1016/j.worlddev.2012.11.002

Demirguc-kunt, A., Klapper, L., 2012. “Measuring financial inclusion. The Global findex database." Policy Res. Work. Pap. 6025, World Bank 6025, 1-61. https://doi.org/10.1596/978-0-8213-9509-7

Demirgüç-Kunt, A., Klapper, L., 2012. Financial inclusion in Africa: an Overview. Policy Res. Work. Pap. 6088, World Bank.

Demirgüç-Kunt, A., Klapper, L., Singer, D., 2013. Financial inclusion and legal discrimination against women: evidence from developing countries. Policy Res. Work. Pap. 6416, World 
Bank.

Demirguc-kunt, A., Klapper, L., Singer, D., Oudheusden, P. Van, Ansar, S., Hess, J., 2015. The Global Findex Database 2014: The Promise of Mobile Money to Increase Financial inclusion. Findex notes \#2014-9, World Bank Gr. 1-4.

Demirguc-Kunt, A., Klapper, L., Singer, D., Van Oudheusden, P., 2015. The Global Findex Database 2014: Measuring Financial Inclusion around the World. Policy Res. Work. Pap. 7255, World Bank, Washington, DC. https://doi.org/10.1596/1813-9450-7255

Demirgüç-kunt, A., Levine, R., 2008. Finance and Economic Opportunity. Policy Res. Work. Pap. World Bank 1-32. https://doi.org/10.1093/oxfordhb/9780199640935.013.0029

Dermish, A., Kneiding, C., Leishman, P., Mas, I., 2012. Branchless and Mobile Banking Solutions for the Poor: A Survey of the Literature. Innov. Technol. Governance, Glob. 6, 81-98.

Dias, D., Mckee, K., 2010. Branchless Banking 2010: Who's Served? At What Price? What's Next? Inf. Commun. Dev. https://doi.org/10.1596/1813-9450-5664

Dupas, P., Robinson, J., 2013a. Savings Constraints and Microenterprise Development: Evidence from a Field Experiment in Kenya. Am. Econ. J. Appl. Econ. 5, 163-192. https://doi.org/10.1257/app.5.1.163

Dupas, P., Robinson, J., 2013b. Why don't the poor save more? Evidence from health savings experiments. Am. Econ. Rev. 103, 1138-1171. https://doi.org/10.1257/aer.103.4.1138

Economides, N., Jeziorski, P., 2016. Mobile Money in Tanzania. Forthcom. Mark. Sci. 1-57.

Gash, M., Gray, B., 2015. Understanding Household Resilience of the Poor in Burkina Faso Interim Report. Consult. Gr. to Assist Poor Work. Pap.

Heckman, J.J., Ichimura, H., Todd, P., 1998. Matching As An Econometric Evaluation Estimator. Rev. Econ. Stud. 261-294. https://doi.org/10.1111/1467-937X.00044

Helmore, K., 2011. Tanzania: Linking savings groups to Mobile Banking. Access Africa Tech. Learn. No.2.

Honohan, P., Beck, T., 2007. Making Finance Work for Africa, Finance. World Bank. https://doi.org/10.1596/978-0-8213-6909-8 
Jack, W., Suri, T., 2014. Risk sharing and transactions costs: Evidence from Kenya's mobile money revolution. Am. Econ. Rev. 104, 183-223. https://doi.org/10.1257/aer.104.1.183

Karlan, D., Ratan, A.L., Zinman, J., 2014. Savings by and for the Poor: A Research Review and Agenda. Rev. Income Wealth 60, 36-78. https://doi.org/10.1111/roiw.12101

Kendall, J., 2010. A Penny Saved: How Do Savings Accounts Help the Poor? Financ. Access Initiat. Focus Note 1-22. https://doi.org/http://dx.doi.org/10.2139/ssrn.198246

Kendall, J., Maurer, B., Machoka, P., Veniard, C., 2011. An Emerging Platform: From Money Transfer System to Mobile Money Ecosystem. Innov. Technol. Governance, Glob. 6, 49-64. https://doi.org/10.1162/INOV_a_00100

Kendall, J., Schiff, R., Smadja, E., 2013. Sub-Saharan Africa: A major potential revenue opportunity for digital payments. McKinsey Q.

Ky, S., Rugemintwari, C., Sauviat, A., 2017. Does mobile money affect saving behavior? Evidence from a developing country. Forthcom. J. African Econ. 1-36. https://doi.org/10.1093/jafeco/ejx028

Lepoutre, J., Oguntoye, A., 2018. The (non-)emergence of mobile money systems in Sub-Saharan Africa: A comparative multilevel perspective of Kenya and Nigeria. Technol. Forecast. Soc. Change 131, 262-275. https://doi.org/10.1016/j.techfore.2017.11.010

Lin, F., 2018. Cross-country diffusion of ideology via FDI: Micro-evidence from China. Econ. Transit. 26, 3-34. https://doi.org/10.1111/ecot.12139

Mas, I., 2012a. Making Mobile Money Daily Relevant. SSRN Electron. J. 1-32. https://doi.org/10.2139/ssrn.2018807

Mas, I., 2012b. Beyond Products: Building Integrated Customer Experiences (2012), The New Microfinance Handbook: A Financial Market System Perspective. The World Bank (2013).

Mas, I., 2010. Savings for the Poor. World Econ. 11, 1-12.

Mas, I., Mayer, C., 2011. Savings as Forward Payments : Innovations on Mobile Money Platforms. Forthcom. as Chapter 10 "Financial Incl. poverty alleviation Bank. unbanked." Essam Yassin Mohammed Zenebe Bashaw Uraguchi (eds). London Routledge. 1-14. 
Mas, I., Porteous, D., 2015. Pathways to Smarter Digital Financial Inclusion. Forthcom. J. Financ. Transform. 1-28.

Mbiti, I., David Weil, 2016. Mobile Banking: the Impact of M-Pesa in Kenya. African Successes, Vol. III Mod. Dev. Edwards, Johnson, Weil. https://doi.org/10.1007/s13398-014-0173-7.2

Mbiti, I., Weil, D.N., 2011. Mobile Banking: The Impact of M-PESA in Kenya. Natl. Bur. Econ. Res. https://doi.org/10.3386/w17129

Morawczynski, O., 2009. Saving Through the Mobile Phone - The Case of M-PESA. MicroBanking Bull. 7-14.

Morawczynski, O., Pickens, M., 2009. Poor People Using Mobile Financial Services: Observations on Customer Usage and Impact from M-PESA. Consult. Gr. to Assist Poor.

Mothobi, O., Grzybowski, L., 2017. Infrastructure deficiencies and adoption of mobile money in Sub-Saharan Africa. Inf. Econ. Policy 000, 1-9. https://doi.org/10.1016/j.infoecopol.2017.05.003

Munyegera, G.K., Matsumoto, T., 2016. Mobile Money, Remittances, and Household Welfare: Panel Evidence from Rural Uganda. World Dev. 79, 127-137. https://doi.org/10.1016/j.worlddev.2015.11.006

Nair, A., Kloeppinger-Todd, R., 2007. Reaching Rural Areas with Financial Services: Lessons from Financial Cooperatives in Brazil, Burkina Faso, Kenya, and Sri Lanka. Agric. Rural Dev. World Bank.

Oliveira, P., Von Hippel, E., 2011. Users as service innovators: The case of banking services. Res. Policy 40, 806-818. https://doi.org/10.1016/j.respol.2011.03.009

Pande, R., Cole, S., Sivasankaran, A., Bastian, G.G., Durlacher, K., 2012. Does poor people's access to formal banking services raise their incomes? EPPI-Centre, Social Science Research Unit, Institute of Education University of London.

Porteous, D., 2006. The Enabling Environment for Mobile Banking in Africa. Bankable Front. Assoc. Bost. USA 1-57.

Ramada-Sarasola, M., 2012. Can Mobile Money Systems Have a Measurable Impact on Local 
Development? Available SSRN. https://doi.org/10.2139/ssrn.2061526

Shem, A.O., Misati, R., Njoroge, L., 2012. Factors driving usage of financial services from different financial access strands in Kenya. Savings Dev. 36, 71-89.

Thieba, D., 2013. Les Coopératives D 'Épargne et de Crédit au Burkina : Étude de Cas du Réseau des Caisses Populaires du Burkina Faso. Capra International Inc., Canada.

Triki, T., Faye, I., 2013. Financial inclusion in Africa: an overview. African Dev. Bank.

Van Der Boor, P., Oliveira, P., Veloso, F., 2014. Users as innovators in developing countries: The global sources of innovation and diffusion in mobile banking services. Res. Policy 43, 1594 1607. https://doi.org/10.1016/j.respol.2014.05.003

Wooldridge, J.M., 2002. Econometric Analysis of cross section and panel data, Cambridge, Mass: MIT Press. 


\section{Appendix}

Table A.1. Participants in informal financial mechanisms and disadvantaged groups

\begin{tabular}{|c|c|c|c|c|c|c|}
\hline & \multicolumn{6}{|c|}{ Mean of subsample variables } \\
\hline & $\begin{array}{r}\text { Participants of } \\
\text { informal } \\
\text { mechanisms }\end{array}$ & Low income & $\begin{array}{l}\text { Irregular } \\
\text { income }\end{array}$ & Rural & Female & Less educated \\
\hline & (1) & (2) & (3) & (4) & (5) & (6) \\
\hline MM user & 0.43 & 0.45 & 0.53 & 0.57 & 0.50 & 0.44 \\
\hline Age & 29.08 & 27.63 & 31.31 & 32.27 & 28.60 & 31.54 \\
\hline Married & 0.41 & 0.32 & 0.54 & 0.59 & 0.43 & 0.57 \\
\hline Rural & 0.39 & 0.54 & 0.68 & / & 0.51 & 0.63 \\
\hline Male & 0.34 & 0.36 & 0.46 & 0.52 & l & 0.52 \\
\hline Occupation & 0.87 & 0.71 & 0.92 & 0.90 & 0.80 & 0.99 \\
\hline Irregular income & 0.50 & 0.50 & / & 0.63 & 0.53 & 0.67 \\
\hline $\begin{array}{l}\text { At least one person in } \\
\text { charge }\end{array}$ & 0.56 & 0.52 & 0.53 & 0.51 & 0.53 & 0.53 \\
\hline Education & 2.46 & 2.55 & 2.32 & 2.46 & 2.65 & I \\
\hline Income & 2.42 & / & 2.51 & 2.57 & 2.4 & 2.56 \\
\hline
\end{tabular}

Note: Average values are reported for the whole sample of 405 individuals. 


\section{Table A.2. Mobile money users participating in informal mechanisms who report to have}

reduced the use of informal finance

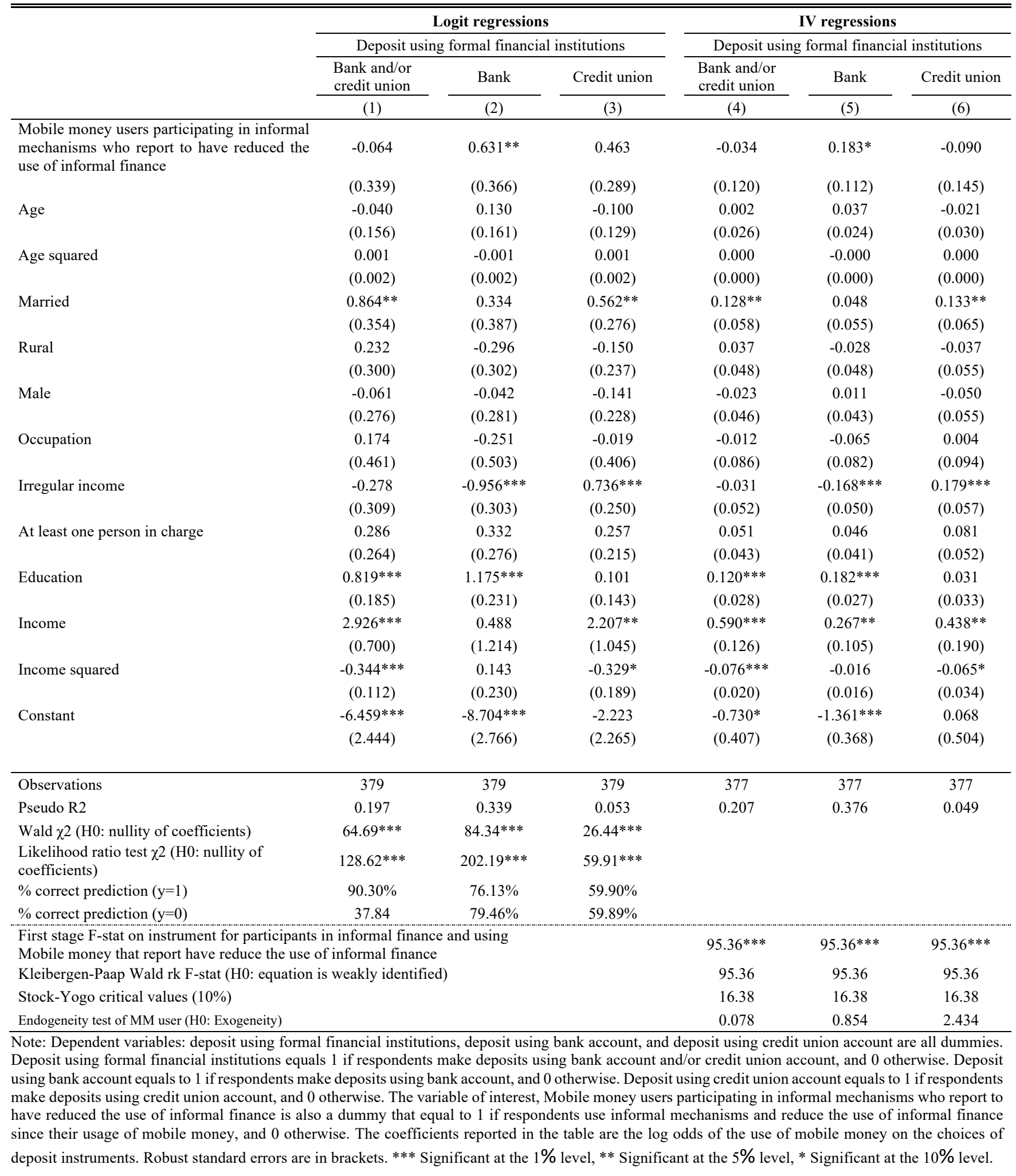


Table A.3. Deposit in mobile money account and individuals' characteristics. (IV Results are also reported).

\begin{tabular}{|c|c|c|c|c|c|c|}
\hline & \multicolumn{6}{|c|}{ Logit regressions } \\
\hline & \multicolumn{6}{|c|}{ Deposit in mobile money account } \\
\hline & $\begin{array}{l}\text { Participating in informal } \\
\text { mechanisms }\end{array}$ & $\begin{array}{l}\text { Low vs. High } \\
\text { income }\end{array}$ & $\begin{array}{l}\text { Irregular vs. Regular } \\
\text { income }\end{array}$ & $\begin{array}{l}\text { Rural vs. } \\
\text { Urban }\end{array}$ & $\begin{array}{l}\text { Female vs. } \\
\text { Male }\end{array}$ & $\begin{array}{l}\text { Less vs. Highly } \\
\text { educated }\end{array}$ \\
\hline & $(1)$ & $(2)$ & $(3)$ & $(4)$ & $(5)$ & $(6)$ \\
\hline MM user $(\beta 2)$ & $\begin{array}{l}5.445^{* * *} \\
(0.790)\end{array}$ & $\begin{array}{l}6.315^{* * *} \\
(1.012)\end{array}$ & $\begin{array}{l}20.255^{* * *} \\
(1.093)\end{array}$ & $\begin{array}{c}6.314 * * * \\
(1.206)\end{array}$ & $\begin{array}{c}5.748 * * * \\
(0.821)\end{array}$ & $\begin{array}{c}6.642 * * * \\
(1.266)\end{array}$ \\
\hline Individuals' characteristics & $\begin{array}{c}-1.642 \\
(10.058)\end{array}$ & $\begin{array}{r}25.976^{* *} \\
(10.564)\end{array}$ & $\begin{array}{c}12.763 * \\
(6.638)\end{array}$ & $\begin{array}{l}-2.715 \\
(8.942)\end{array}$ & $\begin{array}{c}2.801 \\
(8.723)\end{array}$ & $\begin{array}{l}-9.375 \\
(6.554)\end{array}$ \\
\hline MM user $x$ Individuals' characteristics $(\beta 4)$ & $\begin{array}{c}0.483 \\
(1.293)\end{array}$ & $\begin{array}{l}-1.325 \\
(1.314)\end{array}$ & $\begin{array}{c}-15.578^{* * *} \\
(1.332)\end{array}$ & $\begin{array}{l}-1.264 \\
(1.467)\end{array}$ & $\begin{array}{l}-0.521 \\
(1.262)\end{array}$ & $\begin{array}{l}-2.231 \\
(1.453)\end{array}$ \\
\hline Individuals' characteristics $x$ Controls included & YES & YES & YES & YES & YES & YES \\
\hline Controls included & YES & YES & YES & YES & YES & YES \\
\hline $\begin{array}{l}\text { Wald: } \\
(\beta 2)+(\beta 4)\end{array}$ & $\begin{array}{c}5.928^{* * *} \\
(1.024)\end{array}$ & $\begin{array}{c}4.990^{* * *} \\
(0.838)\end{array}$ & $\begin{array}{c}4.678^{* * *} \\
(0.752)\end{array}$ & $\begin{array}{c}5.051^{* * *} \\
(0.836)\end{array}$ & $\begin{array}{c}5.227 * * * \\
(0.959)\end{array}$ & $\begin{array}{c}4.411 * * * \\
(0.713)\end{array}$ \\
\hline Observations & 376 & 378 & 378 & 378 & 378 & 381 \\
\hline Pseudo R2 & 0.634 & 0.627 & 0.641 & 0.634 & 0.630 & 0.616 \\
\hline Wald $\chi^{2}$ (H0: nullity of coefficients) & $158.92 * * *$ & $130.03 * * *$ & & $106.22 * * *$ & $133.92 * * *$ & $327.80 * * *$ \\
\hline Likelihood ratio test $\chi^{2}$ (H0: nullity of coefficients) & $355.56^{* * *}$ & $351.11 * * *$ & $358.46^{* * *}$ & $354.72 * * *$ & $352.84 * * *$ & $344.55 * * *$ \\
\hline$\%$ correct prediction $(\mathrm{y}=1)$ & $92.86 \%$ & $90.91 \%$ & $92.21 \%$ & $92.21 \%$ & $93.51 \%$ & $94.16 \%$ \\
\hline \multirow[t]{5}{*}{$\%$ correct prediction $(\mathrm{y}=0)$} & $86.94 \%$ & $87.05 \%$ & $86.61 \%$ & $87.95 \%$ & $86.61 \%$ & $86.34 \%$ \\
\hline & \multicolumn{6}{|c|}{ IV regressions } \\
\hline & \multicolumn{6}{|c|}{ Deposit in mobile money account } \\
\hline & $\begin{array}{l}\text { Participating in informal } \\
\text { mechanisms }\end{array}$ & $\begin{array}{l}\text { Low vs. High } \\
\text { income }\end{array}$ & $\begin{array}{l}\text { Irregular vs. Regular } \\
\text { income }\end{array}$ & $\begin{array}{l}\text { Rural vs. } \\
\text { Urban }\end{array}$ & $\begin{array}{l}\text { Female vs. } \\
\text { Male }\end{array}$ & $\begin{array}{l}\text { Less vs. Highly } \\
\text { educated }\end{array}$ \\
\hline & (1) & $(2)$ & (3) & (4) & (5) & (6) \\
\hline MM user $(\beta 2)$ & $\begin{array}{c}0.736^{* * *} \\
(0.052)\end{array}$ & $\begin{array}{c}0.763 * * * \\
(0.049)\end{array}$ & $\begin{array}{c}0.746^{* * *} \\
(0.050)\end{array}$ & $\begin{array}{c}0.742 * * * \\
(0.053)\end{array}$ & $\begin{array}{c}0.757 * * * \\
(0.052)\end{array}$ & $\begin{array}{c}0.783 * * * \\
(0.042)\end{array}$ \\
\hline Individuals' characteristics & $\begin{array}{c}0.014 \\
(0.704)\end{array}$ & $\begin{array}{l}1.890^{* * *} \\
(0.604)\end{array}$ & $\begin{array}{c}0.116 \\
(0.569)\end{array}$ & $\begin{array}{l}-0.356 \\
(0.596)\end{array}$ & $\begin{array}{l}-0.030 \\
(0.513)\end{array}$ & $\begin{array}{l}-0.269 \\
(0.517)\end{array}$ \\
\hline MM user $x$ Individuals' characteristics $(\beta 4)$ & $\begin{array}{l}-0.045 \\
(0.076)\end{array}$ & $\begin{array}{l}-0.101 \\
(0.075)\end{array}$ & $\begin{array}{l}-0.091 \\
(0.077)\end{array}$ & $\begin{array}{l}-0.058 \\
(0.075)\end{array}$ & $\begin{array}{l}-0.097 \\
(0.075)\end{array}$ & $\begin{array}{c}-0.162 * * \\
(0.081)\end{array}$ \\
\hline Individuals' characteristics $\mathrm{x}$ Controls included & YES & YES & YES & YES & YES & YES \\
\hline Controls included & YES & YES & YES & YES & YES & YES \\
\hline $\begin{array}{l}\text { Wald: } \\
(\beta 2)+(\beta 4)\end{array}$ & $\begin{array}{c}0.691 * * * \\
(0.055)\end{array}$ & $\begin{array}{c}0.662 * * * \\
(0.057)\end{array}$ & $\begin{array}{c}0.655^{* * *} \\
(0.059)\end{array}$ & $\begin{array}{c}0.684 * * * \\
(0.053)\end{array}$ & $\begin{array}{c}0.660^{* * * *} \\
(0.055)\end{array}$ & $\begin{array}{c}0.621 * * * \\
(0.069)\end{array}$ \\
\hline Observations & 374 & 376 & 376 & 376 & 376 & 376 \\
\hline R-squared & 0.663 & 0.660 & 0.666 & 0.662 & 0.666 & 0.654 \\
\hline First stage F-stat on instrument for MM user & $413.66^{* * *}$ & $471.81^{* * *}$ & $404.01 * * *$ & $448.75 * * *$ & $526.52 * * *$ & $340.48 * * *$ \\
\hline First stage F-stat (MM user $x$ Individuals' characteristics) & $550.75^{* * *}$ & $494.82 * * *$ & $13.15^{* * *}$ & $9.68^{* * *}$ & $553.65^{* * *}$ & $434.42 * * *$ \\
\hline Kleibergen-Paap Wald rk F-stat (H0: equation is weakly identified) & 8.81 & 8.79 & 9.10 & 8.79 & 8.39 & 13.42 \\
\hline Stock-Yogo critical values $(10 \%)$ & 7.03 & 7.03 & 7.03 & 7.03 & 7.03 & 7.03 \\
\hline Endogeneity test of MM user (H0: Exogeneity) & 0.200 & 0.662 & 0.245 & 0.329 & 0.892 & 1.146 \\
\hline
\end{tabular}

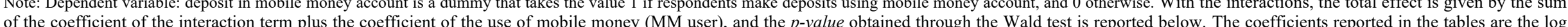
odds of the use of mobile money on the choices of deposit instruments. Robust standard errors are in brackets. ** Significant at the $1 \%$ level, ** Significant at the $5 \%$ level, * Significant at the $10 \%$ level. 
Table A.4. Correlation matrix

\begin{tabular}{|c|c|c|c|c|c|c|c|c|c|c|c|c|c|c|c|c|c|c|c|}
\hline & $\begin{array}{c}\text { Deposit in } \\
\text { bank } \\
\text { and/or } \\
\text { credit } \\
\text { union }\end{array}$ & $\begin{array}{l}\text { Deposit } \\
\text { in bank }\end{array}$ & $\begin{array}{c}\text { Deposit } \\
\text { in credit } \\
\text { union }\end{array}$ & $\begin{array}{l}\text { Deposit in } \\
\text { informal } \\
\text { mechanisms }\end{array}$ & $\begin{array}{c}\text { Deposit } \\
\text { in mobile } \\
\text { money }\end{array}$ & MM user & $\begin{array}{l}\text { Participants in } \\
\text { informal } \\
\text { mechanisms }\end{array}$ & Distance & Age & Age squared & Married & Rural & Male & Occupation & $\begin{array}{l}\text { Irregular } \\
\text { income }\end{array}$ & $\begin{array}{l}\text { At least } \\
\text { one } \\
\text { person in } \\
\text { charge }\end{array}$ & Education & Income & $\begin{array}{l}\text { Income } \\
\text { squared }\end{array}$ \\
\hline $\begin{array}{l}\text { Deposit in bank } \\
\text { and/or credit } \\
\text { union }\end{array}$ & 1 & & & & & & & & & & & & & & & & & & \\
\hline Deposit in bank & 0.55 & 1 & & & & & & & & & & & & & & & & & \\
\hline $\begin{array}{l}\text { Deposit in } \\
\text { credit union }\end{array}$ & 0.66 & 0.02 & 1 & & & & & & & & & & & & & & & & \\
\hline $\begin{array}{l}\text { Deposit in } \\
\text { informal } \\
\text { mechanisms }\end{array}$ & -0.16 & -0.16 & 0.11 & 1 & & & & & & & & & & & & & & & \\
\hline $\begin{array}{l}\text { Deposit in } \\
\text { mobile money }\end{array}$ & 0.09 & 0.14 & 0.05 & -0.12 & 1 & & & & & & & & & & & & & & \\
\hline MM user & 0.05 & 0.14 & 0.00 & -0.12 & 0.78 & 1 & & & & & & & & & & & & & \\
\hline $\begin{array}{l}\text { Participants in } \\
\text { informal } \\
\text { mechanisms }\end{array}$ & -0.19 & -0.19 & 0.08 & 0.76 & -0.16 & -0.13 & 1 & & & & & & & & & & & & \\
\hline Distance & -0.03 & -0.10 & 0.01 & 0.10 & -0.65 & -0.89 & 0.11 & 1 & & & & & & & & & & & \\
\hline Age & 0.20 & 0.23 & 0.01 & -0.24 & -0.02 & -0.03 & -0.19 & 0.04 & 1 & & & & & & & & & & \\
\hline Age squared & 0.20 & 0.22 & 0.01 & -0.23 & -0.04 & -0.04 & -0.19 & 0.06 & 0.99 & 1 & & & & & & & & & \\
\hline Married & 0.20 & 0.16 & 0.08 & -0.16 & 0.15 & 0.13 & -0.14 & -0.07 & 0.61 & 0.58 & 1 & & & & & & & & \\
\hline Rural & -0.01 & -0.14 & 0.01 & -0.39 & 0.13 & 0.15 & -0.25 & -0.09 & 0.25 & 0.24 & 0.23 & 1 & & & & & & & \\
\hline Male & 0.09 & 0.12 & -0.04 & -0.26 & 0.07 & 0.01 & -0.30 & 0.01 & 0.27 & 0.25 & 0.11 & 0.03 & 1 & & & & & & \\
\hline Occupation & 0.08 & -0.01 & 0.07 & -0.03 & -0.11 & -0.08 & 0.06 & 0.07 & 0.43 & 0.38 & 0.35 & 0.16 & 0.11 & 1 & & & & & \\
\hline $\begin{array}{l}\text { Irregular } \\
\text { income }\end{array}$ & -0.10 & -0.29 & 0.14 & -0.05 & 0.06 & 0.04 & 0.04 & -0.03 & 0.10 & 0.08 & 0.11 & 0.30 & -0.10 & 0.20 & 1 & & & & \\
\hline $\begin{array}{l}\text { At least one } \\
\text { person in } \\
\text { charge }\end{array}$ & 0.06 & 0.07 & 0.08 & 0.07 & 0.09 & 0.11 & 0.06 & -0.10 & -0.00 & -0.01 & 0.02 & -0.03 & -0.01 & 0.05 & 0.01 & 1 & & & \\
\hline Education & 0.28 & 0.45 & 0.02 & -0.07 & 0.19 & 0.16 & -0.19 & -0.13 & -0.15 & -0.14 & -0.17 & -0.23 & 0.02 & -0.39 & -0.36 & -0.01 & 1 & & \\
\hline Income & 0.36 & 0.42 & 0.09 & -0.17 & 0.09 & 0.07 & -0.23 & -0.04 & 0.44 & 0.43 & 0.36 & -0.05 & 0.27 & 0.34 & -0.13 & 0.06 & 0.13 & 1 & \\
\hline Income squared & 0.32 & 0.41 & 0.06 & -0.16 & 0.07 & 0.07 & -0.23 & -0.05 & 0.43 & 0.42 & 0.35 & -0.08 & 0.25 & 0.30 & -0.14 & 0.06 & 0.14 & 0.98 & 1 \\
\hline
\end{tabular}


Table A.5. Computation of probabilities to make deposits in formal financial instruments.

\begin{tabular}{|c|c|c|c|c|c|}
\hline & \multirow[b]{2}{*}{$\begin{array}{l}\text { Coefficients of } \\
\text { interest }^{*} \text { compare }\end{array}$} & \multicolumn{3}{|c|}{ Deposit using formal financial institutions } & \multirow[b]{2}{*}{ Mobile money } \\
\hline & & $\begin{array}{c}\text { Bank and/or credit } \\
\text { union }\end{array}$ & Bank & Credit union & \\
\hline \multirow{3}{*}{ Full sample } & MM user & - & - & - & $74.56 \%$ \\
\hline & Non-MM user & - & - & - & $2.76 \%$ \\
\hline & Difference & & & & $71.80 \%$ \\
\hline \multirow{3}{*}{$\begin{array}{l}\text { Participants in } \\
\text { informal mechanisms }\end{array}$} & MM user & - & $41.72 \%$ & - & $72.87 \%$ \\
\hline & Non-MM user & - & $26.10 \%$ & - & $2.13 \%$ \\
\hline & Difference & & $15.62 \%$ & & $70.74 \%$ \\
\hline \multirow{3}{*}{$\begin{array}{l}\text { Non-participants in } \\
\text { informal mechanisms }\end{array}$} & MM user & - & & - & $72.89 \%$ \\
\hline & Non-MM user & - & & - & $2.81 \%$ \\
\hline & Difference & & & & $70.08 \%$ \\
\hline \multirow{3}{*}{$\begin{array}{l}\text { Mobile money users } \\
\text { participating in } \\
\text { informal mechanisms } \\
\text { (Table A.2) }\end{array}$} & $\begin{array}{l}\text { Reduced using } \\
\text { informal }\end{array}$ & - & $48.78 \%$ & - & - \\
\hline & $\begin{array}{l}\text { Did not reduce using } \\
\text { informal }\end{array}$ & - & $39.29 \%$ & - & - \\
\hline & Difference & & $9.49 \%$ & & \\
\hline \multirow{3}{*}{ Low income } & MM user & $50.55 \%$ & - & - & $68.20 \%$ \\
\hline & Non-MM user & $66.35 \%$ & - & - & $3.48 \%$ \\
\hline & Difference & $15.8 \%$ & & & $64.72 \%$ \\
\hline \multirow{3}{*}{ High income } & MM user & $83.3 \%$ & - & - & $74.27 \%$ \\
\hline & Non-MM user & $69.7 \%$ & - & - & $1.52 \%$ \\
\hline & Difference & $13.6 \%$ & & & $72.75 \%$ \\
\hline \multirow{3}{*}{ Irregular income } & MM user & - & $38.05 \%$ & - & $78.25 \%$ \\
\hline & Non-MM user & - & $23.47 \%$ & - & $12.13 \%$ \\
\hline & Difference & & $14.58 \%$ & & $66.12 \%$ \\
\hline \multirow{3}{*}{ Regular income } & MM user & - & - & - & $100 \%$ \\
\hline & Non-MM user & - & - & - & $70.89 \%$ \\
\hline & Difference & & & & $29.11 \%$ \\
\hline \multirow{3}{*}{ Rural } & MM user & - & - & - & $73.27 \%$ \\
\hline & Non-MM user & - & - & - & $4.88 \%$ \\
\hline & Difference & & & & $68.39 \%$ \\
\hline \multirow{3}{*}{ Urban } & MM user & $50.07 \%$ & - & - & $68.87 \%$ \\
\hline & Non-MM user & $37.87 \%$ & - & - & $1.03 \%$ \\
\hline & Difference & $12.2 \%$ & & & $67.84 \%$ \\
\hline \multirow{3}{*}{ Female } & MM user & $48.87 \%$ & - & - & $69.98 \%$ \\
\hline & Non-MM user & $33.47 \%$ & - & - & $2.95 \%$ \\
\hline & Difference & $15.4 \%$ & & & $67.03 \%$ \\
\hline \multirow{3}{*}{ Male } & MM user & - & - & - & $80.60 \%$ \\
\hline & Non-MM user & - & - & - & $3.67 \%$ \\
\hline & Difference & & & & $76.93 \%$ \\
\hline \multirow{3}{*}{ Less educated } & MM user & - & $29.4 \%$ & $54.57 \%$ & $60.14 \%$ \\
\hline & Non-MM user & - & $16.05 \%$ & $39.52 \%$ & $4.02 \%$ \\
\hline & Difference & & $13.35 \%$ & $15.05 \%$ & $56.12 \%$ \\
\hline \multirow{3}{*}{ Highly educated } & MM user & - & - & $44.42 \%$ & $77.97 \%$ \\
\hline & Non-MM user & - & - & $59.15 \%$ & $1.11 \%$ \\
\hline & Difference & & & $14.73 \%$ & $76.86 \%$ \\
\hline
\end{tabular}

Note: We report in the Table the probability associated with coefficients that are significant at the $1 \%, 5 \%$ or $10 \%$ levels.

$\$$ According to the model, the coefficients of interest are $\beta_{2}$ and $\beta_{2}+\beta_{4}$, or $\gamma_{2}$ and $\gamma_{2}{ }^{+} \gamma_{4}$.

$\$$ In Table A.2, we use a binary independent variable of interest that takes the value one for mobile money users participating in informal mechanisms who report to have reduced the use of informal finance and zero otherwise. 
Table A.6. Distance to the nearest mobile money agent and individuals' characteristics.

\begin{tabular}{|c|c|c|c|c|}
\hline & \multicolumn{4}{|c|}{ Distance to the nearest mobile money agent } \\
\hline & \multicolumn{2}{|c|}{ OLS } & \multicolumn{2}{|c|}{ Ordered Logit } \\
\hline & Coefficient & RSE & Coefficient & RSE \\
\hline Age & 0.008 & $(0.009)$ & 0.011 & $(0.012)$ \\
\hline Age squared & 0.000 & $(0.000)$ & 0.000 & $(0.000)$ \\
\hline Married & -0.187 & $(0.133)$ & -0.228 & $(0.181)$ \\
\hline Rural & $-0.236^{*}$ & $(0.133)$ & -0.289 & $(0.184)$ \\
\hline Male & 0.023 & $(0.134)$ & 0.039 & $(0.180)$ \\
\hline Occupation & 0.251 & $(0.179)$ & 0.333 & $(0.232)$ \\
\hline Irregular income & -0.080 & $(0.134)$ & -0.100 & $(0.181)$ \\
\hline At least one person in charge & $-0.261 *$ & $(0.133)$ & $-0.341 *$ & $(0.183)$ \\
\hline Education & $-0.177 * *$ & $(0.070)$ & $-0.249 * *$ & $(0.098)$ \\
\hline Income & -0.074 & $(0.097)$ & -0.098 & $(0.149)$ \\
\hline Income squared & -0.013 & $(0.017)$ & -0.020 & $(0.028)$ \\
\hline
\end{tabular}

Note: Dependent variable: measure of agent access, takes value ranging from 1 to 5. RSE (robust standard errors) are in brackets. Each raw is a separate regression. We check the exogeneity of the distance to the nearest mobile money agent by examining whether it is correlated with individuals' characteristics in our analysis and find only little evidence. ${ }^{* *}$ Significant at the $1 \%$ level, ${ }^{* *}$ Significant at the $5 \%$ level, $*$ Significant at the $10 \%$ level. 
Table A.7. Check the difference between treated (MM user) and Control (Non-MM user) according to individual characteristics.

\begin{tabular}{|c|c|c|c|c|c|}
\hline \multirow[b]{2}{*}{ Variable } & \multirow[b]{2}{*}{ Sample } & \multicolumn{4}{|c|}{ Mobile money } \\
\hline & & Treated & Control & $\mathbf{t}$ & $p>t$ \\
\hline \multirow[t]{2}{*}{ Age } & Unmatched & 30.316 & 30.614 & -0.41 & 0.684 \\
\hline & Matched & 30.269 & 30.745 & -0.65 & 0.514 \\
\hline \multirow[t]{2}{*}{ Age square } & Unmatched & 960.15 & 997.27 & -0.77 & 0.441 \\
\hline & Matched & 959.32 & 994.65 & -0.74 & 0.458 \\
\hline \multirow[t]{2}{*}{ Married } & Unmatched & 0.542 & 0.407 & 2.64 & 0.009 \\
\hline & Matched & 0.520 & 0.541 & -0.38 & 0.701 \\
\hline \multirow[t]{2}{*}{ Rural } & Unmatched & 0.584 & 0.439 & 2.85 & 0.005 \\
\hline & Matched & 0.566 & 0.587 & -0.41 & 0.682 \\
\hline \multirow[t]{2}{*}{ Male } & Unmatched & 0.526 & 0.497 & 0.56 & 0.574 \\
\hline & Matched & 0.497 & 0.513 & -0.30 & 0.765 \\
\hline \multirow[t]{2}{*}{ Occupation } & Unmatched & 0.821 & 0.873 & -1.40 & 0.161 \\
\hline & Matched & 0.829 & 0.847 & -0.46 & 0.644 \\
\hline \multirow[t]{2}{*}{ Irregular income } & Unmatched & 0.495 & 0.466 & 0.57 & 0.572 \\
\hline & Matched & 0.514 & 0.457 & 1.07 & 0.286 \\
\hline \multirow[t]{2}{*}{ At least one person in charge } & Unmatched & 0.579 & 0.466 & 2.22 & 0.027 \\
\hline & Matched & 0.549 & 0.531 & 0.32 & 0.749 \\
\hline \multirow[t]{2}{*}{ Education } & Unmatched & 2.853 & 2.519 & 3.56 & 0.000 \\
\hline & Matched & 2.777 & 2.798 & -0.21 & 0.835 \\
\hline \multirow[t]{2}{*}{ Income } & Unmatched & 2.700 & 2.540 & 2.08 & 0.038 \\
\hline & Matched & 2.651 & 2.738 & -1.04 & 0.299 \\
\hline \multirow[t]{2}{*}{ Income square } & Unmatched & 7.911 & 6.952 & 2.09 & 0.037 \\
\hline & Matched & 7.600 & 8.144 & -1.07 & 0.285 \\
\hline
\end{tabular}


Table A.8. Results from the full sample.

\begin{tabular}{|c|c|c|c|c|c|c|}
\hline \multirow[b]{2}{*}{ Variable } & \multirow[b]{2}{*}{ Sample } & \multicolumn{5}{|c|}{ Full sample } \\
\hline & & Treated & Controls & Difference & S.E. & T-stat \\
\hline \multirow[t]{2}{*}{$\begin{array}{l}\text { Deposit using bank and/or credit } \\
\text { union }\end{array}$} & Unmatched & 0.742 & 0.672 & 0.070 & 0.047 & 1.50 \\
\hline & ATT & 0.742 & 0.747 & -0.005 & 0.075 & -0.07 \\
\hline \multirow[t]{2}{*}{ Deposit using bank } & Unmatched & 0.484 & 0.333 & 0.151 & 0.050 & 3.01 \\
\hline & ATT & 0.484 & 0.479 & 0.005 & 0.079 & 0.07 \\
\hline \multirow[t]{2}{*}{ Deposit using credit union } & Unmatched & 0.516 & 0.497 & 0.018 & 0.051 & 0.36 \\
\hline & ATT & 0.516 & 0.537 & -0.021 & 0.082 & -0.26 \\
\hline \multirow[t]{2}{*}{ Deposit in informal mechanisms } & Unmatched & 0.359 & 0.497 & -0.138 & 0.050 & 2.73 \\
\hline & ATT & 0.359 & 0.383 & $0-.023$ & 0.080 & -0.29 \\
\hline \multirow[t]{2}{*}{ Deposit using mobile money } & Unmatched & 0.789 & 0.021 & 0.768 & 0.032 & 24.31 \\
\hline & ATT & 0.789 & 0.037 & $0.753 * * *$ & 0.040 & 18.92 \\
\hline
\end{tabular}

Note: ATT stands for the Average Treatment effect on Treated. $* * *$ significant at $1 \%,{ }^{* *}$ significant at $5 \%,{ }^{*}$ significant at $10 \%$. 
Table A.9. Results from individual characteristics.

\begin{tabular}{|c|c|c|c|c|c|c|c|c|c|c|c|}
\hline \multirow[b]{2}{*}{ Variable } & \multirow[b]{2}{*}{ Sample } & \multicolumn{5}{|c|}{ Participants in Informal Mechanisms } & \multicolumn{5}{|c|}{ Non-Participants in Informal Mechanisms } \\
\hline & & Treated & Controls & Difference & S.E. & T-stat & Treated & Controls & Difference & S.E. & T-stat \\
\hline \multirow{2}{*}{$\begin{array}{l}\text { Deposit using bank } \\
\text { and/or credit union }\end{array}$} & Unmatched & 667 & 0.588 & 0.079 & 0.076 & 1.04 & .788 & 0.778 & 0.010 & 0.058 & 0.18 \\
\hline & ATT & 0.667 & 0.736 & -0.069 & 0.122 & 0.57 & 788 & 0.788 & $\mathbf{0}$ & 0.101 & 0.00 \\
\hline Deposit using bank & $\begin{array}{l}\text { Unmatched } \\
\text { ATT }\end{array}$ & $\begin{array}{l}0.431 \\
\mathbf{0 . 4 3 1}\end{array}$ & $\begin{array}{l}0.227 \\
\mathbf{0 . 2 2 2}\end{array}$ & $\begin{array}{l}0.204 \\
\text { 0.208* }\end{array}$ & $\begin{array}{l}0.071 \\
\mathbf{0 . 1 1 7}\end{array}$ & $\begin{array}{l}2.87 \\
1.78\end{array}$ & 517 & $\begin{array}{l}0.456 \\
\mathbf{0 . 5 7 6}\end{array}$ & 0.061 & $\begin{array}{l}.070 \\
.117\end{array}$ & $\begin{array}{l}0.87 \\
\mathbf{0 . 5 1}\end{array}$ \\
\hline \multirow[t]{2}{*}{$\begin{array}{l}\text { Deposit using credit } \\
\text { union }\end{array}$} & Unmatched & 0.466 & 0.467 & -0 & 0 & 0.01 & 56 & 0.467 & 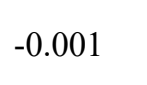 & 0.070 & 0.01 \\
\hline & ATT & 0.466 & 0.517 & -0.051 & 0.117 & 0.43 & 0.466 & 0.517 & -0.051 & 0.117 & 0.43 \\
\hline \multirow{2}{*}{$\begin{array}{l}\text { Deposit using } \\
\text { mobile money }\end{array}$} & Unmatched & 0.708 & 0.021 & 0.688 & 0.049 & 13.92 & 0.839 & 0.022 & 0.817 & 0.041 & 19.68 \\
\hline & ATT & 0.708 & $\mathbf{0}$ & 0.7 & $\mathbf{0 . 0 5 4}$ & 13. & $\mathbf{0 . 8 3 9}$ & $\mathbf{0 . 0 3 4}$ & 0.8 & 0.056 & 14.36 \\
\hline & & \multicolumn{5}{|c|}{ Low income } & \multicolumn{5}{|c|}{ High income } \\
\hline \multirow{3}{*}{$\begin{array}{l}\text { Variable } \\
\text { Deposit using bank } \\
\text { and/or credit union }\end{array}$} & Sample & Treat & Contr & Diffe & S.E. & T-stat & Trea & Contro & Diff & S.E. & T-stat \\
\hline & Unmatched & 0.494 & 0.588 & -0.095 & 0.075 & 1.27 & 0.919 & 0.770 & 0.149 & 0.050 & 2.99 \\
\hline & & 040 & 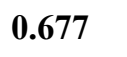 & -0.1 & 0.099 & 1.8 & .919 & 0.766 & 0.1 & 0.086 & 1.79 \\
\hline Deposit using bank & $\begin{array}{l}\text { Unma } \\
\text { ATT }\end{array}$ & & & & $\begin{array}{l}0.063 \\
\mathbf{0 . 0 9 1}\end{array}$ & $\begin{array}{l}0.75 \\
\mathbf{0 . 7 0}\end{array}$ & & $\begin{array}{l}0.483 \\
\mathbf{0 . 5 7 7}\end{array}$ & & $\begin{array}{l}0.070 \\
\mathbf{0 . 1 1 3}\end{array}$ & $\begin{array}{l}2.37 \\
0.64\end{array}$ \\
\hline \multirow[t]{2}{*}{$\begin{array}{l}\text { Deposit using credit } \\
\text { union }\end{array}$} & atched & 0.418 & 0 & -0.063 & 5 & 0.84 & 0.586 & 0.517 & 0.068 & 71 & 6 \\
\hline & ATT & 0.418 & 0.563 & -0.146 & 0.103 & 1.42 & 0.586 & 0.495 & 0.090 & 0.113 & 0.80 \\
\hline \multirow{2}{*}{$\begin{array}{l}\text { Deposit in informal } \\
\text { mechanisms }\end{array}$} & Unmat & 0.475 & 0 & -( & 0 & 1 & 0 & 0 & -0 & 0 . & 1.54 \\
\hline & ATT & 0.475 & 0.613 & -0.138 & 0.109 & 1.26 & 0.277 & 0.277 & $\mathbf{0}$ & 0.106 & 0.00 \\
\hline \multirow{2}{*}{$\begin{array}{l}\text { Deposit using } \\
\text { mobile money }\end{array}$} & Unmatched & 0.722 & 0.029 & 0.692 & 0.049 & 14.25 & 0.838 & 0.012 & 0.826 & 0.041 & 20.03 \\
\hline & ATT & 0.722 & 0.038 & $0.684 * * *$ & 0.061 & 11.16 & 0.838 & 0.009 & $0.829 *$ & 0.046 & 18.00 \\
\hline & & \multicolumn{5}{|c|}{ Irregular income } & \multicolumn{5}{|c|}{ Regular income } \\
\hline & & & & Diff, & S.E. & T-stat & & Controls & & S.E. & T-stat \\
\hline \multirow{2}{*}{$\begin{array}{l}\text { Deposit using bank } \\
\text { and/or credit union }\end{array}$} & Unme & 0.670 & 0.636 & 0.034 & 0.071 & 0.4 & 13 & 0.703 & 0.110 & 0.061 & 1.80 \\
\hline & & 0.670 & 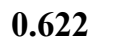 & 0.048 & 08 & 0. & 0.813 & 0.854 & -0.042 & 0.083 & 0.50 \\
\hline Deposit using bank & $\begin{array}{l}\text { Unmat } \\
\text { ATT }\end{array}$ & 0.340 & & & & $\begin{array}{l}3.07 \\
1.80\end{array}$ & $\begin{array}{l}0.625 \\
\mathbf{0 . 6 2 5}\end{array}$ & $\begin{array}{l}0.495 \\
\mathbf{0 . 7 0 0}\end{array}$ & & $\begin{array}{l}0.071 \\
\mathbf{0 . 1 0 8}\end{array}$ & $\begin{array}{l}1.84 \\
0.68\end{array}$ \\
\hline \multirow{2}{*}{$\begin{array}{l}\text { Deposit using credit } \\
\text { union }\end{array}$} & Unmatched & 0.585 & 0.580 & 0.006 & 0.074 & 0.08 & 0.448 & 0.426 & 0.022 & 0.071 & 0.31 \\
\hline & ATT & 0.585 & 0.601 & -0.016 & 0.111 & 0.14 & 0.448 & 0.490 & -0.042 & 0.110 & 0.38 \\
\hline \multirow{2}{*}{$\begin{array}{l}\text { Deposit in informal } \\
\text { mechanisms }\end{array}$} & Unmatched & 0.326 & 0.471 & -0.145 & 0.072 & 2.01 & 0.392 & 0.520 & -0.128 & 0.071 & $1.81 a ̀$ \\
\hline & ATT & 0.326 & 0.400 & -0.074 & 0.120 & 0.61 & 0.392 & 0.418 & -0.026 & 0.114 & 0.230 \\
\hline \multirow{2}{*}{$\begin{array}{l}\text { Deposit using } \\
\text { mobile money }\end{array}$} & Unmatched & 0.798 & 0.045 & 0.752 & 0.048 & 15.62 & 0.781 & 0 & 0.781 & 0.042 & 18.80 \\
\hline & ATT & 0.798 & 0.021 & $0.777 * * *$ & 0.051 & 15.11 & 0.781 & $\mathbf{0}$ & $0.781 * * *$ & 0.042 & 18.42 \\
\hline
\end{tabular}

Note: ATT stands for the Average Treatment effect on Treated. $* * *$ significant at $1 \%, * *$ significant at $5 \%, *$ significant at $10 \%$. 
Table A.10. Results from individual characteristics. (Continued)

\begin{tabular}{|c|c|c|c|c|c|c|c|c|c|c|c|}
\hline \multirow{2}{*}{ Variable } & \multirow[b]{2}{*}{ Sample } & \multicolumn{5}{|l|}{ Female } & \multicolumn{5}{|l|}{ "Male } \\
\hline & & Treated & Controls & Difference & S.E. & T-stat & Treated & Controls & Difference & S.E. & T-stat \\
\hline \multirow{2}{*}{$\begin{array}{l}\text { Deposit using bank } \\
\text { and/or credit union }\end{array}$} & Unmatched & 0.678 & 0.663 & 0.015 & 0.070 & 0.21 & 0.800 & 0.681 & 0.119 & 0.063 & 1.90 \\
\hline & ATT & 0.678 & 0.750 & -0.072 & 0.098 & 0.74 & 0.800 & 0.630 & 0.170 & 0.106 & 1.60 \\
\hline \multirow[t]{2}{*}{ Deposit using bank } & Unmatched & 0.444 & 0.253 & 0.192 & 0.069 & 2.78 & 0.520 & 0.415 & 0.105 & 0.072 & 1.47 \\
\hline & ATT & 0.444 & 0.222 & $0.222 * *$ & 0.093 & 2.38 & 0.520 & 0.480 & 0.040 & 0.124 & 0.32 \\
\hline \multirow{2}{*}{$\begin{array}{l}\text { Deposit using credit } \\
\text { union }\end{array}$} & Unmatched & 0.556 & 0.505 & 0.050 & 0.074 & 0.68 & 0.480 & 0.489 & -0.009 & 0.072 & 0.13 \\
\hline & ATT & 0.556 & 0.683 & -0.128 & 0.106 & 1.23 & 0.480 & 0.430 & 0.050 & 0.124 & 0.40 \\
\hline \multirow{2}{*}{$\begin{array}{l}\text { Deposit in informal } \\
\text { mechanisms }\end{array}$} & Unmatched & 0.516 & 0.591 & -0.075 & 0.073 & 1.02 & 0.218 & 0.404 & -0.186 & 0.065 & 2.86 \\
\hline & ATT & 0.516 & 0.659 & -0.143 & 0.105 & 1.36 & 0.218 & 0.183 & 0.035 & 0.111 & 0.31 \\
\hline \multirow{2}{*}{$\begin{array}{l}\text { Deposit using mobile } \\
\text { money }\end{array}$} & Unmatched & 0.733 & 0.021 & 0.712 & 0.048 & 14.81 & 0.840 & 0.022 & 0.818 & 0.041 & 20.01 \\
\hline & ATT & $\mathbf{0 . 7 3 3}$ & 0.089 & $0.644 * * *$ & 0.060 & 10.83 & 0.840 & $\mathbf{0}$ & $0.840 * * *$ & $\mathbf{0 . 0 3 7}$ & 22.80 \\
\hline & & \multicolumn{5}{|l|}{ Rural } & \multicolumn{5}{|l|}{ Urban } \\
\hline Variable & Sample & Treated & Controls & Difference & S.E. & T-stat & Treated & Controls & Difference & S.E. & T-stat \\
\hline \multirow{2}{*}{$\begin{array}{l}\text { Deposit using bank } \\
\text { and/or credit union }\end{array}$} & Unmatched & 0.757 & 0.663 & 0.094 & 0.065 & 1.44 & 0.722 & 0.679 & 0.042 & 0.069 & 0.62 \\
\hline & ATT & 0.757 & 0.640 & 0.117 & 0.110 & 1.07 & 0.723 & 0.835 & -0.114 & 0.095 & 1.20 \\
\hline \multirow{2}{*}{ Deposit using bank } & Unmatched & 0.387 & 0.289 & 0.098 & 0.069 & 1.42 & 0.620 & 0.368 & 0.252 & 0.072 & 3.49 \\
\hline & ATT & 0.387 & 0.360 & 0.027 & 0.115 & 0.23 & 0.620 & 0.582 & 0.038 & 0.108 & 0.35 \\
\hline \multirow{2}{*}{$\begin{array}{l}\text { Deposit using credit } \\
\text { union }\end{array}$} & Unmatched & 0.532 & 0.494 & 0.038 & 0.073 & 0.52 & 0.494 & 0.500 & -0.006 & 0.075 & 0.08 \\
\hline & ATT & $\mathbf{0 . 5 3 2}$ & 0.432 & 0.099 & 0.121 & 0.82 & 0.494 & 0.544 & -0.051 & 0.109 & 0.47 \\
\hline \multirow{2}{*}{$\begin{array}{l}\text { Deposit in informal } \\
\text { mechanisms }\end{array}$} & tched & 0.195 & 0.305 & -0 . & 0.062 & 1.10 & 0.595 & 0.648 & -0.053 & 0.072 & 0.73 \\
\hline & ATT & 0.195 & 0.212 & -0.018 & 0.108 & 0.16 & 0.595 & 0.551 & 0.044 & 0.106 & 0.42 \\
\hline \multirow{2}{*}{$\begin{array}{l}\text { Deposit using mobile } \\
\text { money }\end{array}$} & Unmatched & 0.793 & 0.037 & 0.756 & 0.048 & 15.62 & 0.785 & 0.009 & 0.775 & 0.042 & 18.64 \\
\hline & ATT & 0.793 & 0.009 & $0.784 * * *$ & 0.050 & 15.56 & 0.785 & 0.025 & $0.759 * * *$ & 0.054 & 14.07 \\
\hline & & \multicolumn{5}{|c|}{ "Less educated } & \multicolumn{5}{|c|}{ "High educated } \\
\hline \multirow{3}{*}{$\begin{array}{l}\text { Variable } \\
\text { Deposit using bank } \\
\text { and/or credit union }\end{array}$} & Sample & Treated & Controls & Difference & S.E. & T-stat & Treated & Controls & Difference & S.E. & T-stat \\
\hline & Unmatched & 0.667 & 0.526 & 0.140 & 0.077 & 1.83 & 0.756 & 0.794 & -0.038 & 0.056 & 0.68 \\
\hline & ATT & 0.667 & 0.597 & 0.069 & 0.106 & 0.66 & 0.756 & 0.764 & -0.008 & 0.074 & 0.11 \\
\hline \multirow[t]{2}{*}{ Deposit using bank } & Unmatched & 0.250 & 0.147 & 0.103 & 0.061 & 1.67 & 0.602 & 0.500 & 0.102 & 0.066 & 1.53 \\
\hline & ATT & 0.250 & 0.097 & $0.153 * *$ & 0.080 & 1.90 & 0.602 & 0.553 & 0.049 & 0.099 & 0.49 \\
\hline \multirow{2}{*}{$\begin{array}{l}\text { Deposit using credit } \\
\text { union }\end{array}$} & Unmatched & 0.597 & 0.421 & 0.176 & 0.077 & 2.28 & 0.447 & 0.559 & -0.112 & 0.067 & 1.67 \\
\hline & ATT & 0.597 & 0.500 & 0.097 & 0.108 & 0.90 & 0.447 & 0.484 & -0.037 & 0.098 & 0.37 \\
\hline \multirow{2}{*}{$\begin{array}{l}\text { Deposit in informal } \\
\text { mechanisms }\end{array}$} & Unmatched & 0.370 & 0.489 & -0.119 & 0.077 & 1.55 & 0.355 & 0.485 & -0.130 & 0.066 & 1.98 \\
\hline & ATT & 0.370 & 0.452 & -0.082 & 0.106 & 0.78 & 0.355 & 0.448 & -0.093 & 0.102 & 0.91 \\
\hline \multirow{2}{*}{$\begin{array}{l}\text { Deposit using mobile } \\
\text { money }\end{array}$} & Unmatched & 0.736 & 0.032 & 0.704 & 0.050 & 14.01 & 0.817 & 0.010 & 0.808 & 0.039 & 20.49 \\
\hline & ATT & 0.736 & 0.028 & $0.708 * * *$ & 0.063 & 11.32 & 0.817 & 0.008 & $0.810 * * *$ & 0.041 & 19.60 \\
\hline
\end{tabular}

Note: ATT stands for the Average Treatment effect on Treated. *** significant at $1 \%$, ** significant at $5 \%$, ${ }^{*}$ significant at $10 \%$. 


\section{NOTES}

${ }^{1}$ In section 3.1, we provide in detail the background on mobile money, formal and informal systems in Burkina Faso.

${ }^{2}$ Rotating savings groups (including ROSCA) often function outside the scope of the formally regulated and supervised financial system. They involve local tradition as well as mutual trust that members reciprocally place in each other and the agreements underlying these mechanisms are generally verbal. In the case of breach of the agreement, enforcement is informal.

${ }^{3}$ Using individual-level data set of mobile money transactions in Tanzania, Economides and Jeziorski (2016) find that mobile money is used for short term purposes to avoid risk associated with holding cash.

${ }^{4}$ These data include the RCPB (le Réseau des Caisses Populaires du Burkina Faso), a credit union that provides formal financial services that cover all the 45 provinces of the country with 185 counters in 2013. For more details, see the RCPB website: www.rcpb.bf.

5 The data are collected for the year 2014.

${ }^{6}$ These initiatives include internet banking, prepaid card, and in particular the mobile money to increase competitiveness in the banking sector.

${ }^{7}$ Note that among the two districts of the rural municipality considered in our study, there is one district where formal financial institutions are inexistent.

${ }^{8}$ In the rural municipality, Saaba, only two formal financial institutions one microfinance and one credit union institutions are present.

${ }^{9}$ We ended up with a final sample of 405 respondents due to mistakes made during the process by some interviewers and respondents alike.

${ }^{10}$ Low income consist of income ranging from 10,000 to 50,000 FCFA; and high income consist of income more than 50,000 FCFA.

11 Savings being one of the main reasons why individuals may make deposits, we alternatively consider it as the dependent variable instead of deposits and obtain similar conclusions. To save space, results are not reported but available upon request.

${ }^{12}$ Formal deposit instruments are a combination of bank and credit union accounts. This variable takes the value one if the respondent reports to make deposits using a bank account and/or a credit union account, and takes the value zero otherwise. 
13 Table 2 reports definitions of variables along with their summary statistics.

${ }^{14} \mathrm{We}$ also consider as a dependent variable deposit using mobile money account. The results are reported in Appendix Table A.3.

15 Dupas and Robinson (2013b) and Jack and Suri (2014) use similar modelling/ computation to capture the effect of mobile money for specific groups.

16 In Table A.1 in the Appendix we report statistics on individuals 'characteristics (low and irregular income, rural, women and less educated) and individuals participating in informal financial mechanisms. These statistics highlight that each sample has its distinguishing features.

17 This endogeneity test is proposed by Baum, Schaffer and Stillman (2007) and its statistic is numerically equal to a Hausman test statistic under conditional hemoskedasticity.

${ }^{18}$ Both methods yield similar resultats across all our tables. The only notable differences are that estimates of coefficients are comparatively lower for the IV regression; and the lack of significant relationship between mobile money and deposit in a credit union account for the low level income individuals with the propensity matching score approach.

19 The coefficients reported in all our tables are the log odds of the use of mobile money on the choices of deposit instruments. Computations of probabilities are reported in Appendix Table A.5, for more detail about the formula see (Wooldridge, 2002, p.459).

${ }^{20}$ The correlation matrix is presented in Appendix, Table A.4. We introduced alternatively married and age (that have the highest correlation of 0.61) and obtained similar results.

${ }^{21}$ Considering individuals who are supposed to have a relatively high access to formal financial institutions, the results show that mobile money increases the probability to make deposits in formal financial institutions by $13 \%$ for high income individuals and in a bank account by $12 \%$ for individuals located in urban areas. These results imply that mobile money and formal deposit instruments taken as a whole appear complements for high income individuals, while for individuals located in urban area the complementarity exists only between mobile money and bank accounts. As regards to highly educated individuals, we find that the use of mobile money does not lead them to use a credit union account; it rather decreases their probability to do so by $15 \%$.

${ }^{22}$ They also support our findings on the likelihood of subgroup of individuals to make deposits in mobile money account. The results are reported in appendix, Table A.3. 